\title{
Niektoré aspekty nemanželskej plodnosti a detí narodených mimo manželstva na Slovensku ${ }^{1}$
}

\author{
Branislav Šprocha ${ }^{2}$ - Pavol Tišliar ${ }^{3}$ \\ Centrum spoločenských a psychologických vied SAV, Bratislava \\ Katedra historických vied a stredoeurópskych štúdií FF UCM, Trnava \\ Ústav archeologie a muzeologie FF, Masarykova univerzita, Brno
}

Some Aspects of Extramarital Fertility and Children Born out of Wedlock in Slovakia. The transformation of reproductive behavior in Slovakia after 1989 brought several historically unique and dynamically ongoing changes. One of them is the increase in the number and share of children born out of wedlock. In less than three decades, their representation has increased from less than a tenth to $40 \%$. The historically valid model of reproduction realized almost exclusively in marriage received serious cracks, and Slovak society had to face this important pluralizing factor in reproductive and family behavior. However, this is in contrasts with the almost minimal scientific interest in this issue. Therefore, the main goal of the paper is to try to analyze some selected aspects associated with the process of extramarital fertility and birth out of wedlock. On the one hand, we tried to point out some major developmental changes, on the other hand we tried to identify some differences that could be associated with more frequent births of children of unmarried women, as well as to identify some internal demographic factors behind the increase in the share of illegitimate children since the early $90 \mathrm{~s}$. As our findings show, the youngest women, Roma women and people with low education have a higher chance of having a children out of wedlock in Slovakia. In terms of space, this phenomenon is more often present in women from medium-sized and small settlements, somewhat more often from the rural environment and districts of southern central Slovakia. The main demographic factor behind the increase in the proportion of children born out of wedlock is the growth in the number and proportion of unmarried women, and to a lesser extent, the growth of extramarital fertility.

Sociológia 2021, Vol. 53 (No. 4: 339-376)

https://doi.org/10.31577/sociologia.2021.53.4.13

Key words: Extramarital fertility; children born out of wedlock; transition; Slovakia

\section{Úvod}

Takmer univerzálny model vstupu do manželstva a rodenia detí v manželskom zväzku bol platný na Slovensku ešte na začiatku 90. rokov minulého storočia. (Potančoková a kol. 2008; Šprocha - Tišliar 2016) Až v posledných troch desat'ročiach došlo $\mathrm{k}$ jeho dynamickému rozpadu. V nových spoločenských, politických, kultúrnych a hospodárskych podmienkach sme svedkami nielen výrazného poklesu intenzity vstupovania mladých slobodných mužov a žien do

\footnotetext{
1 Príspevok je výsledkom projektu VEGA č. 2/0064/20 Pokračujúca transformácia rodinného a reprodukčného správania na Slovensku v časovom a priestorovom aspekte.

${ }^{2}$ Korešpondencia: RNDr. Branislav Šprocha, Ph.D., Centrum spoločenských a psychologických vied SAV, Šancova 56, 811 05 Bratislava, Slovenská republika. E-mail: branislav.sprocha@gmail.com

${ }^{3}$ Korešpondencia: prof. PhDr. Pavol Tišliar, PhD., Katedra historických vied a stredoeurópskych štúdií FF UCM v Trnave. Filozofická fakulta Univerzity sv. Cyrila a Metoda v Trnave, nám J. Herdu 2, 91701 Trnava, Slovenská republika. Ústav archeológie a muzeológie, Filozofická fakulta, Masarykova univerzita, Arna Nováka 1, 62000 Brno, Česká republika. Email: tisliar@phil.muni.cz
}

Sociológia 53, 2021, č. 4 
manželstva, ale aj historicky nebývalého nárastu počtu a podielu detí narodených mimo manželský zväzok (bližšie napr. Šprocha - Tišliar 2018). Tieto zmeny sú pritom so sebou úzko previazané, ked’že v dôsledku poklesu prvosobášnosti a predlžovaniu obdobia života mimo manželský zväzok sa početne zväčšuje aj exponovaná populácia žien (a tiež mužov), ktorá je vystavená šanci stat' sa matkou pred uzavretí manželstva. Súčasne s tým niektoré výskumy (napr. Mládek - Širočková 2004; Tydlitátová 2015a,b; Džambazovič - Šprocha 2017) poukazujú aj na premenu kohabitácií, ktoré už neplnia u mladých len funkciu predmanželského testovania vzt'ahu, ale čoraz častejšie sú priestorom naṕlnania reprodukčných zámerov. Nemenej dôležitou $\mathrm{v}$ tomto smere je tiež otázka osamelého materstva, teda či pod fenomén nemanželskej plodnosti a detí narodených mimo manželstva sa nepodpisuje vo väčšej miere aj reprodukcia matiek bez prítomnosti biologických otcov.

Vo všeobecnosti môžeme povedat', že z historického hl'adiska Slovensko dlhodobo patrilo k populáciám, kde pôrodnost' a plodnost' boli úzko spojené so životom v manželstve (bližšie napr. Šprocha - Tišliar 2018). Práve spomínané zvyšovanie dôležitosti nemanželskej plodnosti a zastúpenia detí narodených nevydatým ženám $\mathrm{v}$ kombinácii $\mathrm{s}$ d’alšími transformačnými zmenami v procesoch sobášneho a reprodukčného správania po roku 1989 nepriamo poukazujú na uvol'ňovanie tohto dovtedy pomerne úzkeho prepojenia. Aj napriek tomu, že tento fenomén predstavuje nanajvýš aktuálnu výskumnú otázku s d’alekosiahlymi dopadmi na reprodukciu, charakter rodín a domácností a napokon aj celej spoločnosti, na Slovensku je jej venovaná len vel'mi obmedzená pozornost'. Doteraz nebola spracovaná žiadna komplexnejšia analýza, ktorá by dokázala relevantne odpovedat' na otázky, akými zmenami prešiel proces rodenia detí mimo manželstva na Slovensku po roku 1989, ktoré ženy častejšie volia túto reprodukčnú stratégiu, a tiež ktoré (vnútorné) demografické faktory stoja za nárastom podielu detí narodených mimo manželstvo. Navyše doterajšie známe poznatky sú časovo, priestorov i obsahovo fragmentárne a opierajú sa takmer výlučne o agregované údaje, pričom individuálny mikroprístup je $\mathrm{v}$ podstate prehliadaný.

$\mathrm{V}$ dôsledku toho je hlavným ciel'om príspevku snaha o analýzu vybraných znakov nemanželskej plodnosti a rodenia detí narodených mimo manželský zväzok na Slovensku a ich zmien v čase s dôrazom na obdobie od začiatku 90. rokov. V d'alšej časti sa pokúsime nájst' odpoved' na otázku, či na Slovensku existujú rozdiely v zastúpení nemanželských detí medzi vybranými skupinami žien (napr. z hl'adiska rodinného stavu, najvyššieho dosiahnutého vzdelania, miesta bydliska a pod.), ako sa tieto prípadné rozdiely vyvíjajú v čase. Snahou bude pritom využit' nielen agregovaný makroprístup, ale uvedené zistenia budeme verifikovat' aj prostredníctvom individuálnych údajov. Nemenej dôležitou bude tiež snaha o určenie smeru a intenzity vplyvu hlavných 
vnútorných demografických faktorov (rodinný stav, vek, intenzita manželskej a nemanželskej plodnosti), ktoré mohli stát' za rastúcim podielom detí narodených mimo manželstva na Slovensku od začiatku 90. rokov.

Niektoré teoretické aspekty premeny nemanželskej plodnosti na Slovensku

Koexistencia a kombinácia viacerých inštitucionálnych, kultúrnych, spoločenských a politických faktorov spolupôsobiacich do konca 80. rokov na Slovensku a v d’alších krajinách bývalého východného bloku (pozri napr. Sobotka 2011), ktoré režim upevňoval a prehlboval viedli k vel'mi silnému príklonu ku skorému a takmer univerzálnemu vstupu slobodných mužov a žien do manželstva a následne aj rodičovstva (Potančoková a kol. 2008; Šprocha Tišliar 2016, 2018). Pôsobením centrálnej štátnej regulácie v rôznych sférach, ako aj nastaveniu štátnej populačnej politiky sa tak $\mathrm{v}$ tomto priestore unifikoval demografický vývoj, ktorý predtým vykazoval pomerne značnú rôznorodost' (Filadelfiová - Cuperová 2000). Reprodukčné stratégie sa na tento špecifický socialistický kontext v oblasti politík zamestnanosti, podpory rodiny a celkovej spoločenskej klímy adaptovali (Potančoková 2013). Kým v krajinách bývalého západného bloku bol skorý vstup do manželstva a rodičovstva prekážkou pre spokojný život v období vynárajúcej sa dospelosti (Arnett 2004; Vaskovics 2001), pre mnohých mladých $\mathrm{z}$ východného bloku bol vstupenkou k samostatnosti (van de Kaa 1994). Existujúce špecifické podmienky minulého režimu nevytvárali v odkladaní materských a rodičovských dráh atraktívnu alternatívu (Sobotka 2011), pričom jednoznačne preferoval oficiálne párové súžitie muža a ženy stvrdené sobášom. Neexistovala žiadna výrazná alternatíva voči rodinnému životu (Džambazovič 2015). Ako dodáva Možný a Rabušic (1992), rodinná politika v socialistickom Československu doslova zvádzala mladých l'udí uzatvárat' manželstvá skoro vo vel'kej miere a rodičovstvo tak realizovat' až v manželskom zväzku. Rozhodnutie stat' sa rodičom a žit' v manželstve bolo vel'mi racionálnym a efektívnym rozhodnutím aj v dôsledku t'ažkostí pri získavaní bývania pre slobodných a nezosobášené ši bezdetné páry. (Džambazovič 2012) Systém extenzívnej a egalitárnej sociálnej starostlivosti sprevádzajúci l'udí „od kolísky až po hrob“ tak na jednej strane limitoval alternatívne reprodukčné stratégie mladých l’udí, no súčasne znižoval náklady spojené s materstvom a rodičovstvom (Sobotka 2011). Jednotlivé nástroje sociálnych politík pritom boli úzko previazané na obdobie po uzatvorení manželstva, pričom socialistický režim jednoznačne uprednostňoval manželskú rodinu pred inými formami rodinného života a jednotlivcami (Kvapilová 2000). Ako dopíňa Džambazovič (2015), okrem toho dôležitý vplyv si zachovávali aj tradície, ktoré mali hlboké kultúrno-historické ukotvenie v hodnotových orientáciách väššiny obyvatel'ov Slovenska. Výrazné rodinné hodnoty, vysoké postavenie rodičovskej roly a manželstva súviseli so silne pretrvávajúcim 
vplyvom krest’anskej výchovy $\mathrm{v}$ rodinách a s dedičstvom reprodukčných vzorcov z minulosti (Džambazovič 2015: 17).

Výsledkom pôsobenia týchto faktorov bolo, že po druhej svetovej vojne sa tak na Slovensku ešte viac upevnilo úzke prepojenie plodnosti so sobášnost’ou a životom v manželstve. Nepriamo o tom svedčí aj skutočnost', ked' čoraz častejšie tehotenstvá mladých žien a dievčat $\mathrm{v}$ dôsledku postupnej spoločenskej legitimizácie predmanželskej sexuality (Potančoková 2013) v kombinácii s výrazne obmedzenými spol’ahlivými kontracepčnými možnost’ami, pri nedostatočnej sexuálnej výchove, neznamenali nárast počtu slobodných matiek a nemanželských detí, ale zvyšovanie počtu predmanželských koncepcií. Tehotenstvo mladej ženy tak znamenalo jasný signál k uzavretiu manželského zväzku ešte pred tým, ako sa diet’a narodí (pozri tiež Džamabazovič 2015). Dostupné štatistické údaje pritom hovoria, že na Slovensku na konci 80. a začiatku 90. rokov viac ako polovica všetkých prvých detí narodených vydatým ženám bola počatá ešte pred vstupom do manželstva (Šprocha Tišliar 2018). Ako dodáva Potančoková (2009), nad rizikom rozpadu takéhoto často narýchlo uzavretého manželského zväzku $\mathrm{z}$ donútenia $\mathrm{v}$ dôsledku tehotenstva partnerky prevažovala potreba legitimizovat' diet'a sobášom a vyhnút' sa tak spoločenským sankciám spojeným so slobodným materstvom. V tomto zmysle dopíňa Džambazovič (2015), že mohlo íst' aj o racionálne rozhodnutie nakol'ko sa so sobášom a zakladaním manželskej rodiny s det'mi spájali viaceré zvýhodnenia.

Kým v krajinách bývalého východného bloku sme boli svedkami určitej homogenizácie reprodukčného správania, na Západe sa od polovice 60. rokov minulého storočia štáty začali postupne diferencovat' (Bartoňová 2001). Táto tranzícia však nemala vo všetkých európskych krajinách rovnaký priebeh, intenzitu a nezačínala simultánne (Lesthaeghe - Moors 2000). Mladé generácie odmietli správanie svojich rodičov (Sullerotová 1998), postavili sa odmietavo $\mathrm{k}$ úlohe rodiny a $\mathrm{v}$ životných postojoch preferovali individulizmus a osobnú slobodu(Bartoňová 2001: 45). Ako uvádzajú van de Kaa (1987) a Lesthaeghe (1995), zmeny v ich reprodukčnom správaní boli tak významné a ich pričiny tak kvalitatívne nové, že dostali označenie druhý demografický prechod. $\mathrm{K}$ dôležitým zmenám $\mathrm{v}$ reprodukčnom a rodinnom správaní okrem iného (bližšie napr. van de Kaa 1997; Kuijsten 1995) patrilo aj odkladanie vstupov do manželstva, rast rozvodovosti a významu rôznych foriem nemanželských párových spolužití, čo sa spoločne odzrkadl'ovalo pod dynamické štrukturálne premeny z hl'adiska rodinného stavu. Rastúca variabilita nemanželských súžití spolu s ich spoločenskou akceptáciou ako alternatívy k manželstvu, ako aj akceptáciou slobodného materstva prispievali k nárastu počtu a podielu detí narodených mimo manželský zväzok (van de Kaa 1997). Tieto zmeny sú dôležitou súčast'ou teoretického konceptu druhej demografickej tranzície 
a práve $\mathrm{s}$ ňou a so zmenami hodnotových a normatívnych rámcov u mladých l'udí je spájané podl’a niektorých autorov (napr. Esteve a kol. 2012; Lesthaeghe - Surkyn 2002; Lesthaeghe 2010; Sobotka a kol. 2003; Surkyn - Lesthaeghe 2004; Potančoková 2013) aj vysvetl'ovanie dôvodov rozpájania prepojenia medzi manželstvom a rodičovstvom. Dôraz na slobodu, sebarealizáciu a sebavyjadrenie a odmietanie podriad'ovania života vonkajším autoritám, povinnostiam a sociálnym normám môže viest' $\mathrm{k}$ vytvoreniu nepotrebnosti legislatívneho ukotvenia párových zväzkov (Hamplová 2007).

Celý komplex transformačných posunov po roku 1989, zmena inštitucionálneho kontextu, postupné hodnotové premeny a dozaista aj generačná skúsenost' s dôsledkami skorých manželstiev vyprovokovaných tehotenstvom partnerky viedli podl'a Potančokovej (2013) k prehodnoteniu stratégie legitimizácie prichádzajúceho diet'at'a. Ako d’alej dodáva (Potančoková 2013: 110), zmena kontextu reprodukcie tento proces významne urýchlila, pretože otvorila možnosti inovácie zabehnutých rutinných vzorcov správania. Slabnutie vplyvu pôvodných spoločenských noriem, sociálnej kontroly a sankcií spojených $\mathrm{s}$ rodičovstvom mimo manželstva spolu s prehlbujúcim sa dôrazom na individualizáciu, kvalitu vzt’ahu partnerov ako dôležitého faktora pre uzavretie manželstva, vplývajú pozitívne na rastúcu nemanželskú plodnost' a podiel detí narodených mimo manželský zväzok (Potančoková 2013).

Hodnotové a normatívne teoretické zdôvodnenie rastu mimomanželskej plodnosti a podielu detí narodených mimo manželstva $\mathrm{v}$ sebe implicitne obsahuje predpoklad, že nevydaté matky sú častejšie z prostredia vyznávajúceho liberálne, postmoderné hodnoty, dosiahli dostatočné vzdelanie, čo im umožňuje určit' si vlastný životný štýl bez ohl'adu na spoločenské normy a tiež majú dostatočné finančné zázemie, aby tieto zámery dokázali samé realizovat' (Katrňák 2006).

Ako však ukazujú niektoré čiastkové česko-slovenské údaje (napr. Potančoková 2012 a 2013; Šalamounová - Nývlt 2006; Šprocha - Tišliar 2019; Zeman 2007) mimomanželská plodnost' a podiel detí narodených mimo manželský zväzok je síce pomerne značne diferencovaný podl'a najvyššieho dosiahnutého vzdelania, ale s negatívnym vzdelanostným gradientom, ked' s rastúcim vzdelaním sa znižuje váha detí narodených nevydatým ženám. Rovnako viaceré predchádzajúce analýzy (napr. Jurčová a kol. 2010; Bleha a kol. 2014; Šprocha a kol. 2019) poukazujú na pretrvávanie určitých priestorových rozdielov v zastúpení detí narodených mimo manželstva na Slovensku. Obdobne ako v Česku (pozri napr. Nývlt - Šalamounová 2004; Šalamounová Šamanová 2005) ide najmä o okresy s problematickým socio-ekonomickým profilom.

Preto niektorí autori (napr. Rychtaříková 2006; Katrňák 2006; Matulník 1998) sa pri vysvetl'ovaní rastúcej nemanželskej plodnosti v česko-slovenskom 
priestore skôr opierajú o teoretický koncept vplyvu štrukturálnych premenných, resp. vysvetlujú tento fenomén ako odraz krízového až deviačného správania. Racionálne až ekonomizujúce rozhodnutie, čiže ekonomická kalkulácia ziskov a strát pri vstupe do manželstva verzus život slobodnej (prípadne osamelej) matky predstavuje ústredný motív tohto štrukturálneho prístupu (Vondráčková a kol. 2014). Ako d’alej dodávajú autorky (Vondráčková a kol. 2014: 145), argumenty vychádzajú z nastavenia sociálnej politiky štátu a sociálneho systému, ktorý síce manifestačne podporuje rodiny s det'mi, latentne však rozširuje rady slobodných matiek, pre ktoré je ekonomicky výhodné zvolit' stratégiu nemanželsky narodeného diet’at'a.

Pre ženy s nízkym vzdelaním je nízkokvalifikovaný muž s neistým postavením na trhu práce a s nízkym často nepravidelným príjmom nie príliš atraktívny manželský partner (Chaloupková 2007). Ako naznačujú výsledky niektorých zahraničných výskumov (Edin 2000; Walter 2001), v takomto prípade ženy radšej nevstupujú do manželstva s nádejou, že sa ich situácia zlepší, alebo nájdu lepšie situovaného partnera. Friedman a kol. (1994) a v nadväznosti tiež Vašková (2006) v tomto smere poukazujú na aspekt, kedy slobodné materstvo môže predstavovat' pre mladé ženy s nízkym vzdelaním krátkodobé riešenie ich neistej situácie. Vo svojej teórii redukcie neistoty Friedman a kol. (1994) poukazujú na skutočnost', že ak má človek možnost' výberu volí takú situáciu (aj ked' s určitou dávkou rizika), u ktorej vie aspoň do určitej miery odhadnút' konzekvencie svojho správania. Ako dopĺn̆a Hamplová (2007: 152) jednou zo stratégií, ako neistotu znižit', je vol'ba takej aktivity, ktorá predurčí vývoj d'alších udalostí, aj napriek tomu, ked' toto predurčenie nemusí mat' vždy pozitívne dopady na život daného aktéra. Rodičovstvo mladých nevydatých žien často v problematickej životnej a ekonomickej situácii by tak mohlo byt' pragmatickou reakciou, kedy existuje len vel'mi obmedzený zoznam alternatívnych životných stratégií, z ktorých dokážu čerpat' istotu a sociálne ukotvenie (Hamplová 2007: 152). Vašková (2006) k tomu dodáva, že materstvo je u žien s problematickým prístupom $\mathrm{k}$ vyššiemu vzdelaniu a následne aj oficiálnemu trhu práce jedným $z$ hlavných zdrojov identity a statusu vo svojom miestnom spoločenstve. Zaujímavé výsledky v tomto smere priniesol aj výskum Hamplovej a Řehákovej (2006), ktorý ukázal, že v regiónoch s problematickými ekonomickými podmienkami sa riziko nemanželskej plodnosti u vel'mi mladých žien výrazne zvyšuje, kým $\mathrm{v}$ regiónoch $\mathrm{s}$ lepšou hospodárskou situáciou išlo skôr o staršie ženy. To by mohlo naznačovat' na aspekt, ked' vel'mi mladé ženy volia stratégiu slobodného materstva ako nástroj, prostredníctvom ktorého čelia nedostatku iných životných príležitostí, kým u starších pravdepodobne lepšie ekonomicky zaistených žien nemanželská plodnost' súvisí skôr s inými ako ekonomickými dôvodmi (Hamplová Řeháková 2006). 
Obidva hlavné teoretické prístupy predpokladajú, že mimomanželská plodnost' je výsledkom zámernej vol'by (Vondráčková a kol. 2014). Ako však dopíňajú Vondráčková a kol. (2014: 145), sociologické teórie a empirické zistenia doteraz nedospeli k jednoznačnému záveru, či dôvodom nemanželskej plodnosti je slobodné rozhodnutie jedinca/jedincov, alebo je príčinou nejaká prekážka, ktorá môže pôsobit' na individuálnej i štruktúrnej úrovni. Okrem toho je potrebné tiež doplnit', že existuje viacero d’alších možných príčin, ktoré žena vo svojich rozhodovacích procesoch len t'ažko môže ovplyvnit' (napr. nedostatok vhodných partnerov $\mathrm{v}$ danej spoločnosti, partner odmieta stup do manželstva, absencia konkrétneho jedinca a pod.) (bližšie Vondráčková a kol. 2014).

\section{Dáta a metódy}

Zdrojom údajov pre naše analýzy sú bežne nedostupné anonymizované primárne údaje Štatistického úradu Slovenskej republiky (d'alej ŠÚ SR) z každoročného vyčerpávajúceho Hlásenia o narodení rady Obyv 2-12. Tie sme $\mathrm{v}$ čase písania príspevku $\mathrm{v}$ digitálnej podobe mali $\mathrm{k}$ dispozícii pre obdobie rokov $1992-2019$. Z nich sme na základe premennej rodinný stav matky pri narodení diet'at'a identifikovali všetky prípady pôrodov detí v manželstve a mimo manželstva a k nim všetky zbierané informácie o samotnom pôrode a predovšetkým pre naše účely o matke diet’at'a.

Pri makroprístupe $\mathrm{k}$ problematike rodenia detí mimo manželstva a podielu nemanželských detí išlo konkrétne o vek ženy, jej najvyššie dosiahnuté vzdelanie, rodinný stav, národnost', miesto bydliska a poradie narodeného diet'at'a. Analyzovali sme pritom nielen samotné diferencie medzi skupinami, so snahou určit', ktoré ženy častejšie rodia deti mimo manželský zväzok, ale tiež sme sa pokúsili identifikovat', ako sa tieto diferencie menili od začiatku 90. rokov.

Za účelom poskytnutia širšieho časového rámca pri analýze procesu plodnosti žien $v$ manželstve a mimo manželstva boli využité aj údaje o počte živonarodených detí a štruktúra žien podl'a veku (5-ročných vekových skupín) a rodinného stavu z verejne dostupnej databázy DATACube ŠÚ $\mathrm{SR}^{4}$. Z nich boli následne konštruované čisté miery (miery 1. kategórie) plodnosti vydatých a nevydatých žien podla vekových skupín.

Anonymizované primárne údaje z Hlásení o narodení boli následne použité aj pri individuálnom analytickom mikroprístupe, prostredníctvom ktorého sme sa snažili overit' predchádzajúce získané výsledky $\mathrm{z}$ agregovaných vstupných údajov. Za účelom určenia vplyvu vybraných premenných na rodenie detí $\mathrm{v}$ manželstve alebo mimo manželstva bola použitá metóda binárnej logistickej

4 Databáza je dostupná online na stránke http://datacube.statistics.sk/ 
regresie. Závislou premennou $\mathrm{v}$ tomto prípade je narodenie diet’ata mimo manželstva, teda slobodnej, rozvedenej alebo ovdovenej žene (1), resp. narodenie diet'at'a vydatej žene (0). Do vysvetl'ujúceho modelu sme v zmysle predchádzajúceho makroprístupu použili tieto nezávislé premenné:

1) vek ženy $(1=$ do 20 rokov, $2=20-24$ rokov, $3=25-29$ rokov, $4=30-34$ rokov, $5=35-39$ rokov, $6=40$ a viac rokov),

2) biologické poradie pôrodu ( 1 = prvý pôrod, $2=$ druhý pôrod, 3 = tretí a d’alší pôrod),

3) najvyššie dosiahnuté vzdelanie $(1=$ základné a bez vzdelania, $2=$ stredoškolské bez maturity, 3 = stredoškolské s maturitou, $4=$ vysokoškolské),

4) národnost' ( 1 = slovenská, 2 = mad’arská, 3 = rómska, 4 = iná),

5) kraj miesta bydliska $(1=$ Bratislavský, $2=$ Trnavský, $3=$ Trenčiansky, $4=$ Nitriansky, 5 = žilinský, $6=$ Banskobystrický, $7=$ Prešovský, $8=$ Košický),

6) miesto bydliska $(1=$ mesto, 2 = vidiecke sídlo $)$,

7) vel'kostná skupina obce miesta bydliska $(1=$ do 1000 obyvatel'ov, $2=$ od 1000 do $2000,3=$ od 2000 do $5000,4=$ od 5000 do $10000,5=$ od 10000 do $50000,6=$ od 500000 do $100000,7=100000$ a viac obyvatel'ov).

Rast podielu detí narodených mimo manželstva je možné z hl'adiska primárnych demografických faktorov vysvetlit' zmenou rodinného stavu žien $\mathrm{v}$ reprodukčnom veku, d’alej zvyšovaním alebo znižovaním intenzity rodenia detí v manželstve alebo mimo manželstva, ako aj samotnou zmenou vekovej štruktúry žien $\mathrm{v}$ reprodukčnom veku. Za účelom identifikácie vplyvu týchto komponentov na nárast zastúpenia nemanželských detí sme aplikovali dekompozičnú techniku vyvinutú das Guptom (1994) a aplikovanú na tieto účely v práci Smith a kol. (1996).

Samotný podiel detí narodených mimo manželstva je vo všeobecnosti daný pomerom medzi počtom narodených detí nevydatým ženám a celkového počtu narodených detí.

podiel $^{\text {mimo }}=\frac{N^{\text {mimo }}}{N^{\text {spolu }}} \cdot 100$

Čitatel' tohto vzt'ahu je následne výsledkom intenzity rodenia nemanželských detí a počtom nevydatých žien $\mathrm{v}$ reprodukčnom veku (najčastejšie $\mathrm{x}=15-49$ rokov):

$N^{\text {mimo }}=\sum_{x} f_{x}^{\text {mimo }} \cdot P_{x}^{\text {nevydaté }}$ 
Ten je možné d’alej vyjadrit' aj v zmysle:

$N^{\text {mimo }}=\sum_{x} \frac{N_{x}^{\text {mimo }}}{P_{x}^{\text {nevydaté }}} \cdot \frac{P_{x}^{\text {spolu }}}{P^{\text {spolu }}} \cdot \frac{P_{x}^{\text {nevydaté }}}{P_{x}^{\text {spolu }}}$

Menovatel' vo vzt'ahu (1) predstavuje súčet detí narodených vydatým a nevydatým ženám, a preto je možné uviest':

$N^{\text {spolu }}=N^{\text {mimo }}+N^{\text {vmanžel }}$

a teda:

$N^{\text {spolu }}=\sum_{x} \frac{N_{x}^{\text {mimo }}}{P_{x}^{\text {nevydaté }}} \cdot \frac{P_{x}^{\text {spolu }}}{P^{\text {spolu }}} \cdot \frac{P_{x}^{\text {nevydaté }}}{P_{x}^{\text {spolu }}}+$

$+\sum_{x} \frac{N_{x}^{v \text { manž }}}{P_{x}^{\text {vydaté }}} \cdot \frac{P_{x}^{\text {spolu }}}{P^{\text {spolu }}} \cdot \frac{P_{x}^{\text {vydaté }}}{P_{x}^{\text {spolu }}}$

Spojením výrazu (3) a (5) do spoločného vzt’ahu (1) následne získavame komplexné vyjadrenie podielu detí narodených mimo manželstva:

$$
\begin{aligned}
& \text { podiel }^{\text {mimo }}= \\
& =\frac{\sum_{x} \frac{N_{x}^{\text {mimo }}}{P_{x}^{\text {nevydate }}} \cdot \frac{P_{x}^{\text {spolu }}}{P^{\text {spolu }}} \cdot \frac{P_{x}^{\text {nevydaté }}}{P_{x}^{\text {spolu }}}}{\sum_{x} \frac{N_{x}^{\text {mimo }}}{P_{x}^{\text {nevydate }}} \cdot \frac{P_{x}^{\text {spolu }}}{P^{\text {spolu }}} \cdot \frac{P_{x}^{\text {nevydaté }}}{P_{x}^{\text {spolu }}}+\sum_{x} \frac{N_{x}^{\text {vmanż }}}{P_{x}^{\text {vydaté }}} \cdot \frac{P_{x}^{\text {spolu }}}{P^{\text {spolu }}} \cdot \frac{P_{x}^{\text {vydaté }}}{P_{x}^{\text {spolu }}}}
\end{aligned}
$$

Ako sme uviedli vyššie, vo všeobecnosti môžeme hovorit' o 4 primárnych demografických faktoroch, ktoré ovplyvňujú podiel narodených detí mimo manželstva a ich zmeny $\mathrm{v}$ čase prípadne stoja $\mathrm{v}$ pozadí vzniku diferencií medzi populáciami. Ide o vplyv efektu zmeny vekovej štruktúry žien v reprodukčnom veku. Ten označíme ako $\alpha$-efekt. Zmena štruktúry žien podl'a veku a rodinného stavu predstavuje $\beta$-efekt. Posuny v intenzite plodnosti nevydatých žien predstavujú $\gamma$-efekt a $\delta$-efekt je tvorený zmenou intenzity plodnosti vydatých žien. V zmysle uvedených efektov môžeme následne daný výraz (6) zapísat' ako:

podiel $^{\text {mimo }}=\frac{\sum_{x} \alpha_{x} \cdot \beta_{x} \cdot \gamma_{x}}{\sum_{x} \alpha_{x} \cdot \beta_{x} \cdot \gamma_{x}+\sum_{x} \alpha_{x} \cdot\left(1-\beta_{x}\right) \cdot \delta_{x}}$

Ak určíme vo všeobecnosti hodnoty jednotlivých faktorov populácie Slovenska v roku 1990 ako A,B,C,D a pre populáciu Slovenska v roku 2019 v podobe 
a,b,c,d, potom môžeme pre $\beta \gamma \delta$-štandardizovaný podiel detí mimo manželstva získat' vzt'ah:

v populácii 1990:

podiel $_{1990}^{\beta \gamma \delta \text {,stand,mimo }}=\left[\frac{b c d+B C D}{4}+\frac{b c D+b C d+B c d+B C d+B c D+b C D}{12}\right] A$

v populácii 2019:

podiel $_{2019}^{\beta \gamma \delta, \text { stand,mimo }}=\left[\frac{b c d+B C D}{4}+\frac{b c D+b C d+B c d+B C d+B c D+b C D}{12}\right] a$

Vplyv $\alpha$-efektu empiricky odvodíme ako:

podiel $_{2019}^{\beta \gamma \delta \text {,stand,mimo }}-$ podiel $_{1990}^{\beta \gamma \delta \text {,stand,mimo }}=$

$=\left[\frac{b c d+B C D}{4}+\frac{b c D+b C d+B c d+B C d+B c D+b C D}{12}\right](a-A)$

Zostávajúce štandardizované podiely detí narodených mimo manželstva, ako aj empirické vyjadrenie vplyvu jednotlivých efektov získavame analogicky uvedenými vzt'ahmi s príslušnou zmenou fixovaných premenných (faktorov).

Historické pozadie a postavenie Slovenska z pohl'adu nemanželskej plodnosti v európskom priestore

Úzke prepojenie medzi životom $\mathrm{v}$ manželstve, realizáciou reprodukčných zámerov a z toho prameniaci nízky podiel detí narodených mimo manželstva má na Slovensku dlhú historickú tradíciu. Ako dopínajú etnologické výskumy z prvej polovice 20. storočia (napr. Salner 1984; Švecová 1997), kombinácia značného vplyvu cirkvi a silných vnútorných kontrolných mechanizmov miestnych spoločenstiev vytvárali z manželského zväzku jediný legitímny priestor $\mathrm{k}$ rodeniu detí. Naopak nevydaté matky a nemanželské deti boli vnímané vel'mi negatívne. Inštitucionalizovat' rodinu a odsúdit' narodenie diet’at'a bolo predovšetkým v záujme perspektív potomstva a prosperity celej spoločnosti (Švecová 1997: 84). Spomenuté výskumy však tiež poukazujú na častejší výskyt nemanželských detí $\mathrm{v}$ mestskom prostredí a tiež v prostredí novo sa formujúcich vidieckych spoločenských štruktúr roztratených osídlení (kopanice, lazy), kde vplyv vnútorných kontrolných mechanizmov už nemal takú silu, resp. ešte nedošlo $k$ ich plnému etablovaniu. Okrem toho náš výskum z rokov 1919 - 1937 ukázal (Šprocha - Tišliar 2008), že vyššie zastúpenie nemanželských detí bolo možné spájat' tiež s priestorom južného a juhovýchodného Slovenska, osobami cigánskej a židovskej národnosti, v kategórii iná národnost' a najväčšími mestami. Na to, že nie všetky koncepcie sa v tomto období realizovali striktne $\mathrm{v}$ manželskom zväzku poukazuje aj podiel prvých detí narodených do 9 mesiacov od sobáša. Ako ukázali dostupné údaje z rokov 
1925 - 1937, zastúpenie predmanželských koncepcií sa pohybovalo na úrovni $20 \%$. To znamená, že až jedná pätina zo všetkých prvých manželských detí bola pravdepodobne počatá ešte pred tým ako dvojica vstúpila do manželstva. Zaujímavé informácie $\mathrm{k}$ tejto problematike tiež priniesli dáta o legitimizácii nemanželských detí. Išlo o legislatívny akt, ktorým sa nemanželským det’om prisúdilo právne postavenie manželských detí. Najčastejšie išlo o dodatočné uzavretie manželstva medzi biologickými rodičmi. Ako však ukázali publikované údaje z medzivojnového obdobia, do 4 rokov od narodenia nemanželského diet’at'a sa k legitimizácii pristúpilo len v 1-4 prípadov (Šprocha - Tišliar 2008).

Z uvedeného stručného prehl'adu je zrejmé, že aj ked' $z$ historického hl'adiska na Slovensku existovali silné spoločenské mechanizmy kontrolujúce realizáciu koncepcií v manželskom zväzku, predsa len čast' reprodukcie sa týkala nevydatých žien. Potvrdzujú to napokon aj samotné empirické údaje o zastúpení detí narodených mimo manželstva a samotná úroveň plodnosti nevydatých žien.

Podiel detí narodených mimo manželstva sa na území Slovenska podl'a uhorských štatistík pred prvou svetovou vojnou pohyboval na úrovni $8 \%$. Nárast intenzity sobášnosti a s ňou spojená kompenzačná fáza plodnosti, ku ktorej došlo na začiatku 20. rokov minulého storočia (bližšie pozri napr. Šprocha - Tišliar 2008, 2016, 2018) znamenali dočasný mierny pokles podielu nemanželských detí pod hranicu $7 \%$. Následný vývoj však bol v znamení postupného nárastu, ktorý vrcholil v prvej polovici 30. rokov na takmer $9 \%$. Po odznení najhorších dopadov hospodárskej krízy sa podiel detí narodených mimo manželstva postupne znižoval až klesol pod $8 \%$. Údaje týkajúce sa populácie oklieštenej Slovenskej republiky signalizujú, že tento vývoj pokračoval, ked'že v rokoch 1940 - 1943 dosiahol predmetný ukazovatel' hranicu 7,0-7,5\%. K tomu pravdepodobne prispeli aj viaceré snahy vtedajších politických činitel'ov o „obrodenie slovenskej rodiny“ s niektorými prvkami špecifickej pronatalitne zameranej populačnej politiky. (bližšie napr. Tišliar 2013) Prechod frontu a s ním spojené rôzne hraničné situácie priniesli v roku 1945 nárazový nárast podielu detí narodených mimo manželstva, a to až na úroveň $11 \%$. Nasledujúci vývoj najprv poznačený oživením sobášnosti a manželskej reprodukcie (napr. Šprocha - Tišliar 2018; Vaňo a kol. 2000) a následne $\mathrm{v}$ čoraz väčšej miere aj spomínaným komplexom špecifických životných podmienok kreovaných počas minulého režimu viedli $\mathrm{k}$ poklesu podielu detí narodených nevydatým ženám a ich stabilizácii na vel'mi nízkej úrovni. Napríklad od začiatku 50. do konca 60. rokov tvorili nemanželské deti len približne $5 \%$ z celkového počtu narodených detí na Slovensku. Koniec 60. rokov síce priniesol určitý mierny nárast na hranicu $6 \%$, no nasledujúci komplex pronatalitných a na legitímne uzavreté manželské zväzky mladých 
rodín s det'mi zameraných opatrení viedol nielen $\mathrm{k}$ určitému oživeniu reprodukcie vydatých žien, ale tiež podmienil d’alší pokles podielu detí narodených mimo manželský zväzok opätovne pod úroveň $5 \%$. Pomerne skoré vyprchanie pozitívneho vplyvu spomínaných opatrení na reprodukčnú klímu sa odrazilo aj na návrate rastového trendu podielu nemanželských detí už koncom 70. rokov. Niektoré sociologické výskumy (napr. Možný 1987) tak už v druhej polovici 80. rokov signalizovali na premenu rodinných štartov práve $\mathrm{v}$ spojitosti s mierne rastúcim podielom detí narodených mimo manželstva. Na sklonku 80. rokov tak opätovne na Slovensku tvorili deti nevydatých žien približne $7 \%$. Nasledujúce obdobie však prinieslo historicky bezprecedentné zmeny a dynamický nárast. Už v prvej polovici 90 . rokov podiel detí narodených mimo manželstva prekročil hranicu $10 \%$ a do začiatku 21 . storočia sa zdvojnásobil. Pri takmer nezmenenej dynamike tento trend pokračoval aj $\mathrm{v}$ d'alšom desat'ročí a vyvrcholil na úrovni $40 \%$, na ktorej sa od roku 2015 stabilizoval.

\section{Obrázok č. 1: Historický vývoj počtu a podielu detí narodených mimo manželstva na Slovensku}

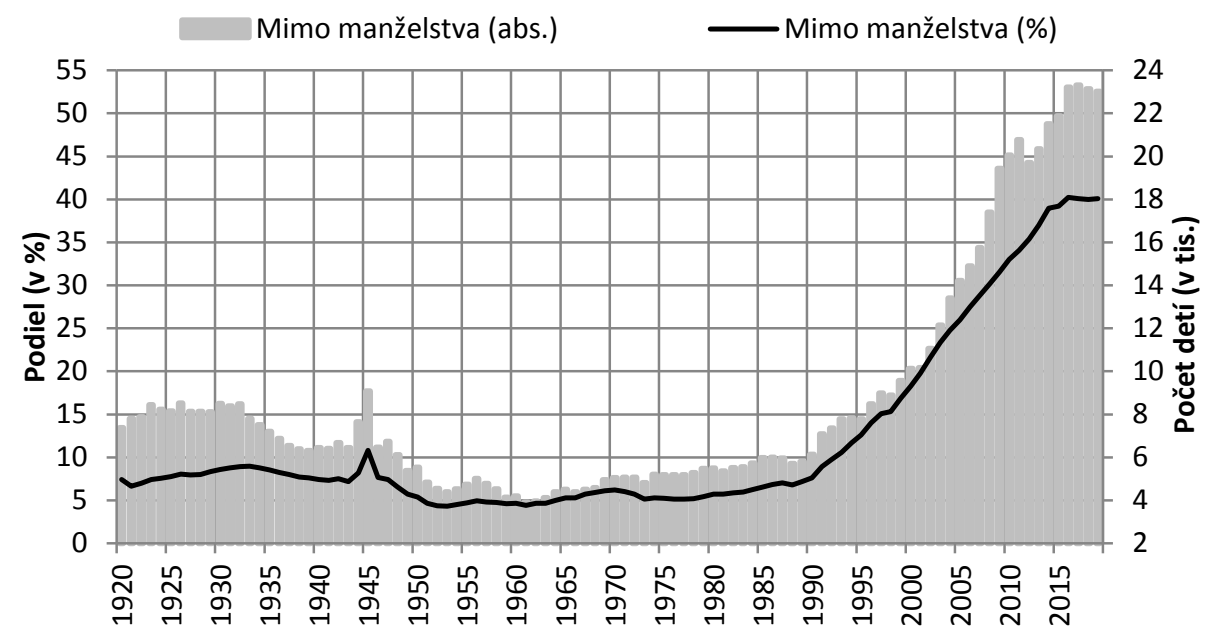

Zdroj údajov: ŠÚ SR; výpočty autorov

V európskom priestore historicky nízky podiel detí narodených mimo manželstva na Slovensku nebol ničím výnimočným. Ešte na začiatku 60. rokov dosahoval tento ukazovatel' nízku úroveň (do $10 \%$ ) v podstate v takmer všetkých populáciách (s výnimkou Islandu ${ }^{5}$ ). Odmietanie tradičnej rodiny, príklon $\mathrm{k}$ individualizmu, osobnej slobode a nezávislosti viedli najmä

\footnotetext{
5 Podl’a údajov EUROSTATu, tesne nad hranicou $10 \%$ sa nachádzali už len Rakúsko a Švédsko spomedzi krajín Západu a na Východe to bolo Lotyšsko.
} 
v severnej a neskôr v západnej Európe k častejšiemu odmietaniu manželských zväzkov (pokles sobášnosti a nárast priemerného veku pri 1. sobáši), k nárastu počtu a podielu mladých l'udí žijúcich $\mathrm{v}$ rôznych formách kohabitácií a uzavretie manželstva prestávalo byt' pre narodenie diet'at’a dôležitým predpokladom (Bartoňová 2001). Na konci 80. rokov tak už môžeme identifikovat' pomerne značné rozdiely, a preto aj legitimita narodených detí sa stala dôležitým diferenčným znakom charakteru reprodukcie populácií týchto dvoch politických blokov (bližšie napr. Monnier - Rychtaříková 1992; Ní Bhrolcháin 1993; Sobotka 2004 a 2011). Detailnejšia analýza však ukazuje, že tento V-Z gradient neplatil úplne. Napríklad vo viacerých krajinách južnej Európy (Španielsko, Taliansko, Grécko, Malta, Cyprus) a vo Švajčiarsku zostával podiel nemanželských detí nad’alej pod hranicou $10 \%$, kým naopak v niektorých populáciách východného bloku so silnou protestantskou tradíciou (Estónsko, Lotyšsko, býv. NDR, Slovinsko) došlo v 70. a v 80. rokoch k pomerne významnému nárastu (Sobotka 2002). Vd’aka tomu už na konci socialistickej éry patrili medzi krajiny s najvyšším podielom detí narodených mimo manželstva v európskom priestore. Ako poznamenáva Bartoňová (2001), vývoj tohto ukazovatel'a tak zretel'ne silne ovplyvňujú spoločenské tlaky a kultúrne odlišnosti jednotlivých krajín. Rovnako Sobotka (2002) a Sobotka s Toulemon (2008) poukazujú na významnú diverzitu rodenia detí mimo manželstva v európskom priestore, ktorú nie je možné vysvetlit' žiadnymi generalizujúcimi geografickými alebo geopolitickými hranicami, ale má skôr pôvod $\mathrm{v}$ hlbších kultúrnych a religióznych tradíciách, ako aj rozdielnych historických podmienkach. Rozpad socialistického bloku a celková spoločenská, hospodárska, politická a kultúrna zmena prispela $\mathrm{v}$ tomto priestore $\mathrm{k}$ spomínanej významnej premene reprodukčného správania. Jedným z jej dôležitých znakov sa stal tiež nárast podielu detí narodených mimo manželstva. Špecifické postavenie v tomto smere mali niektoré historicky protestantské krajiny (napr. Estónsko, býv. NDR), v ktorých zastúpenie nemanželských detí od konca 80 . rokov opät' dramaticky vzrástlo a ich súčasná úroveň sa stabilizovala na hodnotách (50-60 \%). Medzi historicky katolíckymi krajinami Sobotka (2002) v zmysle stupňa tradicionalizmu a sekularizácie rozlišuje katolícke sekularizované, v ktorých podiel nemanželských detí už dosahuje úroveň porovnatel'nú s populáciami Západu (Česko a čiastočne aj Mad’arsko) a pás katolíckych krajín (Pol'sko, Chorvátsko, Litva), ktoré zaznamenali len pozvol'ný rast tohto ukazovatel'a. Podobnú dichotómiu môžeme identifikovat' aj v prípade pravoslávnych krajín, kde Sobotka (2002) rozlišuje „tradičnejšie“ (ako napríklad Bielorusko, Moldavsko, Ukrajina, Severné Macedónsko) a „modernejšie“ (Bulharsko, Rumunsko a Rusko). Vývoj v posledných necelých dvoch desat'ročiach však tento obraz do určitej miery pozmenil. Najvyšší podiel (viac ako $50 \%$ ) nemanželských detí dosahujú okrem štátov severnej Európy aj 
Portugalsko, Holandsko, Slovinsko, Estónsko a Bulharsko. Opačná situácia zostala v niektorých pravoslávnych krajinách južnej Európy (Severné Macedónsko, Grécko) s niečo viac ako desatinou nemanželských detí a tiež na Cypre, v Chorvátsku a Pol'sku, kde dosahujú približne pätinu až štvrtinu. Relatívne nízke zastúpenie nachádzame aj v Litve a Švajčiarsku, kde sa váha detí narodených nevydatým ženám pohybuje na úrovni 25-27\%. Slovensko tak so svojimi $40 \%$ patrí v európskom prostredí v súčasnosti spoločne s Mad’arskom, Rakúskom, Lotyšskom a Írskom ku krajinám s mierne podpriemerným podielom.

\section{Rodenie detí mimo manželstva na Slovensku a jeho zmeny v čase}

Hlavnou skupinou žien, ktorá sa dlhodobo na Slovensku podiel'a na formovaní skupiny nemanželských detí sú slobodné osoby. Získané výsledky dokonca poukazujú na zvýraznenie ich váhy (viac ako $92 \%$ ) na celkovom počte detí narodených nevydatým. Marginálnou skupinou sa stali nemanželské deti ovdovených a kleslo tiež zastúpenie detí rozvedených žien (na približne $7 \%$ ). Za týmito zmenami stojí komplex viacerých transformačných posunov. Jednak sú to štrukturálne faktory, ked' od začiatku 90. rokov došlo na Slovensku $\mathrm{k}$ výraznému nárastu počtu slobodných žien $\mathrm{v}$ reprodukčnom veku. V prípade rozvedených síce identifikujeme rovnaký trend, no ten nebol tak dynamický a navyše posledné desatročie sa nieslo $\mathrm{v}$ znamení určitého poklesu počtu rozvedených žien vo veku 15-49 rokov. Súčasne s tým je možné vidiet' určité zmeny vo vekovej štruktúre týchto osôb. Kým slobodnými sú najmä mladšie ženy, skupina rozvedených sa čoraz častejšie tvorí osobami v poslednej dekáde reprodukčného veku. Tieto vekové posuny v čase, ako aj medzi jednotlivými skupinami potom ovplyvňujú aj samotné šance stat' sa matkou.

To potvrdzuje aj samotná intenzita rodenia detí. Čisté miery plodnosti slobodných žien najmä v posledných dvoch desat'ročiach výrazne vzrástli, a to v podstate vo všetkých vekových skupinách, pričom najdynamickejšie sa tento trend prejavil vo veku 30-39 rokov. Rast intenzity plodnosti nachádzame aj u rozvedených, no najintenzívnejšie práve v najmladších vekoch (do 25 rokov), kde $\mathrm{v}$ populácii Slovenska došlo ku značnej redukcii počtu rozvedených. Naopak vek 35 a viac rokov, v ktorom sa združuje najväčší kontingent rozvedených, sa vyznačoval najmenším rastom intenzity plodnosti a súčasne je to aj vek, v ktorom je šanca stat' sa matkou medzi rozvedenými najnižšia. Stále tak platí, že ak sa žena rozvedie v mladom veku, jej šance stat' sa ešte matkou sú stále pomerne vysoké (a dokonca vyššie ako u slobodných žien), no $\mathrm{s}$ rastúcim vekom pri rozvode značne klesajú. V prípade ovdovených žien vzhl'adom na významné zlepšenie úmrtnostných pomerov mužov v reprodukčnom veku došlo nielen $\mathrm{k}$ výraznej redukcii ich početnosti v tomto vekovom 
spektre, ale čoraz častejšie je táto skupina žien tvorená osobami na konci reprodukčného obdobia, kde šance stat' sa matkou sú už nízke.

Ak celkovú intenzitu rodenia nemanželských detí vyjadríme všeobecnou mierou $^{6}$, potom zistíme, že od začiatku 90 . rokov vzrástol priemerný počet detí narodených slobodným ženám $z$ hodnoty približne $17 \%$ na viac ako $35 \%$. U rozvedených môžeme najprv identifikovat' mierny rast zo 16,5 \%o na 19 \%, no $\mathrm{v}$ poslednom desat'ročí došlo $\mathrm{k}$ určitej redukcii intenzity rodenia detí na približne $15,5 \%$. Určitý rast všeobecnej miery nachádzame aj u ovdovených žien, no celkovo ich intenzita rodenia detí zostáva na nízkej úrovni.

Staršie analýzy Zemana (2007) z českého a Potančokovej (2012) zo slovenského prostredia $\mathrm{z}$ obdobia ukazovali na spojitost' medzi poradím narodeného diet’at'a a jeho legitimitou. Kým v minulosti sa v Česku ako nemanželské rodili najmä deti prvého poradia, obdobie 90 . rokov a začiatku tohto milénia sa nieslo $\mathrm{v}$ znamení zvyšovania podielu aj detí vy̌šśích poradí (Zeman 2007). Analýza povojnového vývoja zastúpenia detí narodených nevydatým ženám na Slovensku však poukazuje na niektoré odlišnosti. Predovšetkým v prvých desat'ročiach po druhej svetovej vojne došlo k určitej konvergencii jednotlivých paritných skupín z pohladu zastúpenia nemanželských detí. Táto homogenizácia charakteru reprodukcie však nedokázala úplne potlačit' existujúce diferencie, a preto aj na Slovensku dlhodobo platilo častejšie rodenie prvých detí mimo manželský zväzok. Na druhej strane podpriemerné zastúpenie dosahovali tieto deti $\mathrm{v}$ prípade druhých a tretích parít. Približne od začiatku 60. rokov však môžeme identifikovat' nárast zastúpenia detí narodených mimo manželstva u vyšších poradí. V skupine 5 a viac detí bol tento trend tak významný, že sa takmer vyrovnala skupine detí prvého poradia. Práve tieto dve paritné skupiny sa vyznačovali nadpriemerne častým rodením nemanželských detí, kým v prípade druhých a tretích detí išlo o marginálnu reprodukčnú stratégiu. $Z$ uvedeného je zrejmé, že medzigeneračne sa presadzujúci model dvoj a čiastočne aj trojdetnej rodiny na Slovensku prispel k tomu, že tieto reprodukčné zámery boli realizované takmer výlučne $\mathrm{v}$ manželskom zväzku. Jednodetnost' a viacdetnost', ktoré sa stali menej vyhl'adávanými $\mathrm{v}$ procese kompletizácie vel'kosti rodiny, boli aj v prostredí všeobecne nízkej nemanželskej plodnosti predsa len častejšie poznačené rodením detí nevydatými ženami. Môžeme sa domnievat', že tieto postupne špecifické reprodukčné stratégie sa v čoraz väčšej miere týkali aj špecifických skupín osôb (napr. ženy s vysokým a vel'mi nízkym vzdelaním, ženy z prostredia marginalizovaných komunít a pod.).

Transformačné zmeny prebiehajúce $v$ slovenskej spoločnosti od začiatku 90. rokov tento obraz čiastočne pozmenili. Predovšetkým je potrebné po-

${ }^{6}$ Všeobecná miera plodnosti vyjadruje priemerný počet narodených detí na 1000 žien príslušného rodinného stavu vo veku 15-49 rokov. 
dotknút', že rast podielu detí narodených mimo manželstva sa dotýkal všetkých paritných skupín. Dá sa tak povedat', že ide o všeobecne akceptovaný fenomén. Súčasne s tým, ale došlo ku značnej heterogenizácii, ked' rozdiely v zastúpení nemanželských detí medzi jednotlivými skupinami žien podla počtu narodených detí sa značne prehíbili. V posledných rokoch sa podiel detí narodených nevydatým matkám na Slovensku viac menej stabilizoval na úrovni $40 \%$, no u detí piateho a vyššieho poradia majú nemanželské pôrody už jasnú prevahu. $\mathrm{V}$ podstate vyrovnaný podiel medzi manželskými a nemanželskými pôrodmi identifikujeme u detí prvého poradia. Pomerne dynamicky rástla aj váha nemanželských detí u štvrtých detí a čiastočne aj tretích detí, no $\mathrm{v}$ poslednej dekáde došlo skôr $\mathrm{k}$ určitej stagnácii. Aj preto dnes platí, že zastúpenie štvrtých detí narodených mimo manželstva je približne na úrovni celoslovenského priemeru. čo môže naznačovat' na existenciu funkčných kohabitácií nahradzujúcich sobáše, teda nielen predmanželské kohabitácie, do ktorých sa ešte pred svadbou „stihli““ narodit’ deti prvého poradia. V prípade tretích detí došlo najprv v 90. rokoch k vyrovnaniu s priemerom Slovenska. Vývoj v poslednom období sa však niesol v znamení menej dynamického rastu, vd’aka čomu sa opätovne táto paritná skupina vyznačuje menej častým rodením nemanželských detí. To jednoznačne platí aj o druhých det'och. V oboch skupinách tak v súčasnosti stále majú zrejmú prevahu pôrody $\mathrm{v}$ manželskom zväzku, ktoré tvoria necelých 70 \%. Podobný scenár nachádza Zeman (2007) aj v Česku. Môžeme predpokladat', že rodenie druhých a tretích detí v manželstve je nad'alej podmienené všeobecne akcentovaným dvojdetným modelom manželskej rodiny. V prípade d'alších detí už do úvahy vstupuje aj skutočnost', že v porovnaní s priemerom Slovenska ide z reprodukčného hl'adiska o neštandardné skupiny žien, ktoré sa okrem iného tiež častejšie vyznačujú nízkym vzdelaním (Šprocha - Tišliar 2019), pochádzajú zo špecifického marginalizovaného prostredia (Šprocha 2014), prípadne sa hlásia k rómskemu etniku (Šprocha - Durček 2017). Navyše sa tieto aspekty pomerne často vzájomne kombinujú, pričom dôležitým znakom je aj vyššia šanca, že do manželstva nevstúpia (napr. Šprocha - Ďurček 2017; Šprocha 2014) a vel'kú čast' (prípadne všetky) svoje reprodukčné zámery budú realizovat' mimo manželský zväzok. V ich prípade je tak možné predpokladat', že realizácia viacerých reprodukčných zámerov mimo manželstva môže naznačovat' na existenciu funkčných kohabitácií, teda nielen predmanželské kohabitácie, do ktorých sa ešte pred svadbou „stihli“" narodit’ prvé deti.

Porovnanie časovania rodenia detí v manželskom zväzku s nemanželskými det'mi na Slovensku v dlhodobom kontexte po druhej svetovej vojne ukazuje na niektoré špecifické rysy rodenia detí nevydatým ženám. Predovšetkým sa ukazuje, že obdobie minulého politického režimu orientované na manželskú rodinu posunulo rodenie detí mimo manželstva a najmä rodenie prvých 
nemanželských detí takmer výlučne do začiatku reprodukčných dráh. Pokles priemerného veku pri narodení prvého diet'at'a síce identifikujeme aj u vydatých žien, no pri nemanželských det'och bol tento proces nielen dynamickejší, ale prebiehal dlhšiu dobu, kým u vydatých osôb sa v podstate už od konca 50. rokov dá hovorit' o určitej stabilite modelu časovania. Na začiatku 70. rokov sa vd’aka tomu vydaté ženy stávali prvýkrát matkami v priemere o takmer dva roky neskôr (takmer v 23. rokoch), ako tomu bolo v prípade nevydatých osôb (približne 21 rokov). Existujúce údaje však podrobnejšiu štrukturálnu analýzu žien rodiacich $\mathrm{v}$ tomto období deti mimo manželstva neumožňujú. Dá sa len predpokladat', že trend posunu nemanželskej plodnosti do čoraz mladšieho veku bol výsledkom akejsi selekcie špecifickej podskupiny žien, u ktorej sa rodenie detí mimo manželský zväzok a súčasne aj skorý začiatok (aj v kontexte vtedajšieho obdobia) reprodukčných dráh stali dôležitou črtou ich modelu reprodukcie. Uvedený jav sa prejavil aj na celkovej štruktúre plodnosti nevydatých žien podl'a veku. Vo veku do 25 rokov sa podiel nemanželskej plodnosti postupne zvýšil až na takmer $70 \%$, kým u vydatých žien ku koncu 80. rokov dosahovali príspevky tejto vekovej skupiny maximum na úrovni približne $55 \%$. Aj to potvrdzuje ako významne bola nemanželská plodnost' žien na Slovensku počas minulého politického režimu koncentrovaná do mladého a vel'mi mladého veku.

Obdobie posledných troch desat'ročí prinieslo významné zmeny v časovaní rodenia detí. Predovšetkým sme svedkami výrazného odkladania realizácie prvých a s tým aj prípadne d’alších reprodukčných zámerov do vyššieho veku (Potančoková a kol. 2008; Potančoková 2013; Šprocha - Tišliar 2016 a 2018). Pozornost' je však venovaná takmer výlučne zmenám celkovej plodnosti bez zohl'adnenia legitimity narodených detí. Preto dôležitou otázkou, na ktorú sa budeme snažit' nájst' odpoved', je či uvedené zmeny sa dotkli aj rodenia nemanželských detí a či boli rovnako dynamické ako v prípade rodenia detí vydatých žien. Doterajšie výsledky o rastúcom podiely detí narodených mimo manželstva, zvyšujúcej sa váhe druhých a d’alších detí na ich zastúpení, ako aj existencii funkčných kohabitácií (Džambazovič - Šprocha 2017) napovedajú, že aj v prípade skupiny nevydatých žien môžeme identifikovat' značné zmeny v časovaní realizácie reprodukčných zámerov. Na druhej strane však stoja niektoré zistenia (napr. Potančoková 2012; Šprocha 2014; Šprocha - Tišliar 2019) signalizujúce, že nemanželské deti sú často doménou špecifických skupín žien, ktoré sa súčasne vyznačujú aj skorým začiatkom reprodukcie. Ked'že sa však rodenie detí mimo manželstva stáva v slovenskej spoločnosti pomerne rozšírený fenomén (o čom hovorí aj $40 \%$ zastúpenie nemanželských detí), dá sa predpokladat' vplyv oboch faktorov.

Podrobná analýza vývoja časovania manželskej a nemanželskej plodnosti potvrdila, že v oboch skupinách došlo na Slovensku k pomerne dynamickému 
odkladaniu rodenia detí do vyššieho veku. Vd’aka tomu sa výrazne zvyšovali hodnoty priemerného veku vydatých a nevydatých žien pri narodení diet’ata. Ked'že hlavným impulzom je predlžovanie obdobia bezdetnosti a teda odkladanie materských štartov, najdynamickejšie v oboch skupinách žien rástol priemerný vek v prípade prvých detí. Dôležitým zistením je tiež, že kým $\mathrm{v}$ prípade vydatých žien sa načasovanie prvého materstva od začiatku 90 . rokov posunulo o viac ako 5 rokov, u nevydatých sa priemerný vek pri prvom pôrode posunul len o niečo viac ako 3,3 roka. Vd'aka tejto disproporcii v dynamike došlo $\mathrm{k}$ výraznému prehĺbeniu diferencií $\mathrm{v}$ načasovaní materských štartov medzi nevydatými a vydatými ženami, ked' prvé diet’a mimo manželstva sa $\mathrm{v}$ priemere rodí o viac ako tri roky skôr. To súvisí nielen so samotným odkladaním materstva, ale aj rozhodnutia vstúpit' do manželstva.

$\mathrm{V}$ súvislosti s týmito zmenami došlo aj $\mathrm{k}$ transformácii vekového rozloženia nemanželskej plodnosti. Predovšetkým sa znížil podiel plodnosti v mladom veku do 25 rokov. Zo spomínaných približne $70 \%$ klesli príspevky až k hranici $45 \%$ a naopak sa takmer zdvojnásobila váha plodnosti vo veku nad 30 rokov, ktorá tak v súčasnosti tvorí takmer jednu tretinu z celej nemanželskej plodnosti. Ak to však porovnáme s vývojom v plodnosti vydatých žien, opätovne môžeme konštatovat', že svojou dynamikou tento vývojový trend značne zaostával. $\mathrm{V}$ manželstve sa v súčasnosti vo veku do 25 rokov koncentruje menej ako $15 \%$ plodnosti, pričom naopak $\mathrm{v}$ druhej polovici reprodukčného veku ide už o prevažnú čast' reprodukcie (53\%).

Popísaný vývoj, úroveň príspevkov, ako aj porovnanie s plodnost'ou vydatých žien jednoznačne poukazuje na formovanie väčšej vekovej pluralizácie v realizácii reprodukčných zámerov u nevydatých žien. Potvrdil sa vy̌̌šie formulovaný predpoklad o stálej existencii skupiny žien, pre ktorých je vol'ba materstva mimo manželský zväzok v mladom veku dôležitou súčastou ich reprodukčných dráh. Súčasne je však tiež zjavné, že aj v skupine nevydatých žien prebieha proces odkladania rodičovstva a jeho rozprestretie do širšieho vekového spektra reprodukčného veku, ako tomu bolo v podmienkach počas minulého politického režimu. Nárast zastúpenia nemanželských detí v druhej polovici reprodukčného veku je pritom možné spojit' nielen so špecifickou skupinou žien, ktoré viaceré svoje reprodukčné zámery realizujú mimo manželský zväzok. Vzhl'adom na zvyšujúci sa podiel prvých detí narodených slobodným matkám vo veku nad 30 rokov je to tiež výsledok rôznych rozhodnutí v nastavení životných a reprodukčných dráh. Jednak môže íst' o absenciu vhodného partnera vo všeobecnosti, prípadne partnera, $\mathrm{s}$ ktorým by žena chcela vstúpit' do manželstva, ako aj vzájomné rozhodnutie páru stat' sa rodičmi bez toho, aby pred narodením diet'at'a vstúpili do manželstva. K tomu môže prispievat' aj rastúca spoločenská akceptácia slobodného materstva, resp. rodičovstva bez nutnosti uzavriet' manželský zväzok. Nepriamo by na to mohol 
poukazovat' aj klesajúci podiel predmanželských koncepcií. Kým na začiatku 90. rokov ešte viac ako polovica všetkých prvých detí narodených v manželstve bola pravdepodobne počatá ešte pred sobášom, v súčasnosti je ich zastúpenie približne polovičné.

Proces transformácie časovania plodnosti nevydatých žien môžeme analyzovat' aj prostredníctvom medzipôrodných intervalov. Kým na začiatku 90. rokov bola priemerná dížka intervalu medzi narodením prvého a druhého diet’at'a mimo manželstva necelých 30 mesiacov, v súčasnosti sa uvedený ukazovatel' už dostal na hranicu takmer 47 mesiacov. Dôležitou informáciou v tomto kontexte je aj zmena rozloženia nemanželských druhých detí podla doby uplynulej od prvého pôrodu ženy. Predovšetkým sme svedkami poklesu rýchlo za sebou idúcich pôrodov. Do 2 rokov od prvého pôrodu sa nevydatým ženám rodilo druhé diet’a takmer $\mathrm{v} 60 \%$ prípadov, kým v súčasnosti ich zastúpenie kleslo o polovicu. Čoraz častejšími sa stáva, že narodenie druhého diet’at'a je aj u nevydatej ženy odkladané a dochádza $\mathrm{k}$ nemu po dlhšej dobe od predchádzajúcej koncepcie. Napríklad v rozmedzí 2 až 4 rokov je to viac ako tretina a po uplynutí 5 a viac rokov dokonca už takmer štvrtina $\mathrm{z}$ celkového počtu druhých detí narodených mimo manželský zväzok.

Existencia špecifických reprodukčných podmienok počas minulého politického režimu v kombinácii s pretrvávajúcou vysokou normativitou manželskej reprodukcie sa prejavovali v podstate naprieč celou spoločnost'ou. Potvrdzuje to aj všeobecne nízky podiel detí narodených mimo manželstva bez ohl'adu na dosiahnuté vzdelanie matiek. V polovici 70. rokov, pre ktoré prvýkrát disponujeme údajmi aj o vzdelaní žien pri pôrode, boli určitou výnimkou len ženy s najnižším vzdelaním. V ich prípade sa rodila mimo manželstva približne desatina detí. V ostatných vzdelanostných skupinách boli nemanželské deti v podstate marginálnou záležitost'ou. Išlo o tri zo sto detí narodených ženám so stredoškolským vzdelaním bez maturity, $2 \%$ dosahovali u žien s úplným stredoškolským vzdelaním a $\mathrm{v}$ prípade absolventiek terciárneho stupňa vzdelávania ich podiel dosahoval len 1,5 \%. Môžeme predpokladat', že dôležitú úlohu pri takejto výraznej vzdelanostnej konvergencii zohrávali aj pred tým prijaté nové opatrenia populačnej politiky favorizujúce manželské zväzky s malými det'mi. Dôležitým zistením bola tiež skutočnost', že deti narodené nevydatým ženám so základným vzdelaním tvorili v polovici 70. rokov až $70 \%$ všetkých nemanželských detí.

Špecifickost' tejto skupiny žien sa prejavila aj v nasledujúcom samotnom vývoji podielu detí narodených mimo manželstva. Práve u žien s najnižším vzdelaním totižto už koncom 70. rokov registrujeme nástup pozvol'ného rastu váhy nemanželských detí. V druhej polovici 80 . rokov sa ich zastúpenie už takmer zdvojnásobilo. Vysvetlenie môžeme hl'adat' jednak v postupnej adaptácii spoločnosti na spomínané pronatalitné a propopulačné opatrenia preferujúce 
manželský zväzok, ale predovšetkým v postupnej spoločenskej selekcii. So základným vzdelaním tak končili svoje vzdelanostné dráhy v čoraz väčšej miere len ženy s problematického prostredia, nefunkčných rodín, marginalizovaných komunít a pod., ktoré na boli sobášnom trhu značne znevýhodnené a nemali väčšie šance zlepšit' svoj status vydajom. Až v polovici 80. rokov sa rastový trend začína prejavovat' aj u žien so stredoškolským vzdelaním bez maturity. Prvé transformačné roky priniesli $\mathrm{v}$ týchto dvoch vzdelanostných skupinách navyše dynamizáciu nastúpených zmien a diferencie sa ešte viac prehĺbili. Môžeme sa domnievat', že prudké socioekonomické posuny výrazným spôsobom otriasli postavením týchto skupín, do značnej miery znevýhodnili ich postavenie $v$ spoločnosti, a to nielen na trhu práce, či finančnej stránke, ale aj na sobášnom trhu. Partnerky s nízkym vzdelaním pri pretrvávajúcej sobášnej homogamii na Slovensku (pozri napr. Šprocha - Džambazovič 2020) prestali byt' vyhl'adávanými, resp. samé neiniciujú vstup do manželstva s rovnako nízko vzdelaným partnerom. Sobáš $s$ takouto osobou by im neumožnil žiadny sociálny vzostup, navyše často ide o nestabilný partnerský zväzok, s osobou neistého postavenia a nízkeho ohodnotenia na trhu práce (Chaloupková 2007). Na druhej strane materstvo často už v mladom veku je pre tieto ženy často nástrojom redukcie životnej neistoty (Friedman a kol. 1994; Hechter - Kanazawa 1997), či cesta ako získat' určitý status v miestnej spoločnosti (Sobotka a kol. 2011).

K rastúcej vzdelanostnej diferenciácii zastúpenia nemanželských detí prispela aj dlhodobá stagnácia vo vývoji u žien súplným stredoškolský a vysokoškolským vzdelaním. $\mathrm{V}$ ich prípade v podstate až obdobie od konca 90. a začiatku 21. storočia môžeme označit' ako iniciačnú fázu dynamizujúceho nárastu nemanželskej plodnosti. Súčasne tiež v týchto dvoch vzdelanostných skupinách platí, že posledné roky sa nesú v znamení opätovne nastupujúcej stagnácie. Dalo by sa povedat', že postupne sa v nich vyselektovala určitá podskupina žien, ktoré akceptujú materstvo mimo manželský zväzok. Pre väčšinu $\mathrm{z}$ nich (takmer $60 \%$ u žien s úplným stredoškolským a $75 \%$ s vysokoškolským vzdelaním) tak nad'alej zostáva dôležitou stratégiou pre realizáciu reprodukčných zámerov najprv vstúpit' do manželstva. Na druhej strane u žien so základným (70 \%) a stredoškolským vzdelaním (60 \%) už jednoznačne dominuje model rodenia detí mimo manželstva. Ešte väčšie rozdiely môžeme identifikovat' pri pohl'ade na charakter začiatku reprodukčných dráh. Len približne štvrtina prvých detí sa ženám s vysokoškolským vzdelaním narodí mimo manželský zväzok, kým u žien s najnižším vzdelaním je to až osem $z$ desiatich detí a dve tretiny v prípade žien so stredoškolským vzdelaním bez maturity.

Dôležitým diferenciačným znakom pri rodení nemanželských detí sa ukazuje byt' aj národnost' matky. Dostupné údaje umožňujú plne porovnat' len 
obdobie od začiatku 90. rokov. Preto nie sme schopní odpovedat' na otázku, ako sa podiel detí narodených mimo manželstva $\mathrm{v}$ jednotlivých národnostných skupinách vyvíjal pred začiatkom transformačného obdobia. $\mathrm{Z}$ dostupných čiastkových informácií sa dá usúdit', že rodenie nemanželských detí bolo predsa len častejším javom u žien hlásiacim sa $\mathrm{k}$ mad’arskej národnosti a predovšetkým u žien identifikovaných $\mathrm{k}$ vtedajšej cigánskej národnosti. Do určitej miery to podporujú aj údaje zo začiatku 90 . rokov, ked' podiel nemanželských detí u žien mad'arskej národnosti prekračoval hranicu $12 \%$ a u Rómiek dosahoval dokonca hodnotu $45 \%$. Naopak ženy slovenskej národnosti mali mierne podpriemerný podiel detí narodených nevydatým osobám (8\%). Vývoj v nasledujúcom období priniesol vo všetkých národnostných skupinách rastový trend. Súčasne však došlo aj ku značnej diferenciácii medzi jednotlivými národnost’ami. Dynamicky rástlo najmä zastúpenie nemanželských detí u žien mad'arskej národnosti. V ich prípade už majú tieto deti miernu prevahu. Ešte výraznejšie dominujú deti nevydatých rómskych žien. Ich zastúpenie $\mathrm{v}$ súčasnosti dosahuje už takmer tri štvrtiny. Rodenie detí mimo manželský zväzok sa tak stalo v tejto národnostnej skupine primárnym znakom reprodukčných stratégií. V majoritnej slovenskej národnostnej skupine sa nárast $\mathrm{v}$ posledných rokoch zastavil na úrovni približne $39 \%$. Jednoznačne najnižšiu dynamiku z pohl'adu zvyšovania podielu nemanželských detí môžeme identifikovat' u osôb hlásiacich sa k iným skupinám národností. Svojím podielom sa pritom na začiatku 90. rokov výraznejšie neodlišovali od celoslovenského priemeru a teda aj osôb slovenskej národnosti. $\mathrm{V}$ súčasnosti sa ich zastúpenie posledné roky pohybuje stabilne pod hranicou $30 \%$. Môžeme sa domnievat', že ženy hlásiace sa k týmto menej početným národnostným skupinám prichádzajú a zostávajú na Slovensku aj vd’aka tomu, že tu nachádzajú manželských partnerov a v prevažnej miere tak realizujú svoje reprodukčné zámery až v manželskom zväzku.

Ako ukazujú niektoré výskumy na Slovensku (Džambazovič - Šprocha 2017; Mládek - Širočková 2004) dominancia detí mimo manželstva môže do značnej miery súvisiet' $\mathrm{s}$ častejšou preferenciou funkčných kohabitácií, osobitost'ami zakladania a existencie manželstva a rodiny, ktoré sú do značnej miery podriadené vnútroskupinovým zvyklostiam a normám (Kumanová Džambazovič 2002). Okrem toho medzi dôležité interné faktory môžeme zaradit' aj vysokú intenzitu plodnosti už vo vel'mi mladom veku (Šprocha 2014), minimálne množstvo alternatívnych životných stratégií, proklamované nízke postavenie najmä mladých a bezdetných žien spolu s (ne-)možnostou sa účinne bránit' počatiu a tiež vel'mi obmedzenými možnost’ami výberu manželského partnera. Tie sú pritom podmienené nielen ich nízkym postavením, rómskym pôvodom a často aj životom $\mathrm{v}$ marginalizovaných segregovaných osadách, ale aj existenciou rôznych nepísaných pravidiel týkajúcich sa okruhu 
možných potenciálnych životných partnerov (Budilová - Jakoubek 2004). Častejší výskyt kohabitácií môžeme pritom pozorovat' aj u žien hlásiacich sa k mad’arskej národnosti (Džambazovič - Šprocha 2017). Okrem toho dôležitým faktorom môže byt' aj častejšia deklarácia mad'arskej národnosti ženami s nízkym vzdelaním, v obciach s početnými skupinami osôb rómskeho etnika najmä na juhu Slovenska.

Niektoré predchádzajúce štúdie (napr. Bleha a kol. 2014 a 2020; Jurčová a kol. 2010) ukazujú, že podiel detí narodených mimo manželstva nie je na Slovensku rozmiestnený rovnomerne, pričom identifikované priestorové diferencie vo svojej podstate pretrvávajú v čase. Do značnej miery to potvrdili aj výsledky našej analýzy. V prvej polovici 90 . rokov najvyššie podiely detí narodených mimo manželstva dosahovala pomerne kompaktná oblast' východného Slovenska tvorená okresmi Rimavská Sobota, Rožňava, Revúca (s 20-23 \%), ku ktorým sa pridávali okresy Spišská Nová Ves, Gelnica, Lučenec, Košice-okolie a Trebišov (s viac ako $15 \%$ ). Výrazne nadpriemernou bola váha nemanželských detí aj v niektorých mestských okresoch Košíc (Košice II, III, IV) a Bratislavy (Bratislava I, Bratislava V). Celkom odlišná situácia pritom bola na severe stredného (okresy Námestovo, Tvrdošín, Bytča, Čadca, Dolný Kubín) a východného Slovenska (okresy Snina, Svidník, Stropkov), kde sa podiel detí narodených mimo manželstva pohyboval od 2 do $6 \%$. Vývoj v nasledujúcom období sa vo všetkých okresoch na Slovensku niesol v znamení nárastu podielu detí narodených mimo manželstva. Jednoznačne najvýraznejšie rástol podiel detí narodených nevydatým ženám v niektorých okresoch (Rožňava, Poltár, Revúca, Gelnica, Vel'ký Krtíš, Lučenec, Levice, Trebišov) na juhu stredného a východného Slovenska. K nim sa pripojili aj niektoré d’alšie celky stredného, či západného Slovenska (okresy Myjava, Šal'a, Turčianske Teplice, Banská Štiavnica, Žiar nad Hronom), v ktorých sa absolútna zmena pohybovala v rozmedzí 40-50 p.b. Naopak najmenej dynamický rast identifikujeme vokresoch na severe Slovenska (Námestovo, Tvrdošín, Dolný Kubín, Kežmarok, Bardejov, Stropkov) a tiež vo viacerých mestských okresoch Bratislavy (Bratislava I, III, IV) a Košíc (Košice I, III, IV).

Ako je z uvedeného zrejmé, transformačné obdobie prispelo ku značnému prehíbeniu už tak pomerne významných regionálnych rozdielov. Súčasne tiež prinieslo určité zmeny v obraze nemanželskej plodnosti na Slovensku. Išlo najmä o zvýraznenie priestorovej diferenciácie v zastúpení nemanželských detí medzi severom a juhom Slovenska, pričom medzi oblasti s najrozšírenejším fenoménom nemanželskej plodnosti prestali patrit' okresy najväčších miest. To potvrdila aj analýza podielu detí narodených mimo manželstva podl'a vel'kostnej skupiny obcí miesta trvalého bydliska matky. Na začiatku 90. rokov jednoznačne platilo, že mestá s viac ako 100 tis. obyvatel'mi boli priestorom 
s najvyšším podielom (takmer $13 \%$ ) detí narodených mimo manželstva. Nadpriemerným bolo ich zastúpenie tiež v sídlach s 2-5 tis. obyvatel'mi (10\%). V ostatných vel'kostných skupinách väčšie rozdiely nenachádzame. Transformačné obdobie však prinieslo značné zmeny a prispelo k významnej heterogenizácii. Najrýchlejšie sa pritom podiel detí narodených mimo manželstva zvyšoval v stredne vel'kých mestách (s 10 až 50 tis. obyvatel'mi), v ktorých v súčasnosti aj dosahuje najvyššie zastúpenie (43-44 \%). Jednoznačne najnižšiu dynamiku rastu pritom zaznamenali vel'ké a najväčšie mestá (s 50 tis. a viac obyvatel'mi). Zaujímavost'ou pritom je, že v prípade miest $\mathrm{s}$ viac ako 100 tis. obyvatel'mi dokonca dochádza v poslednom období k obráteniu trendu a miernemu poklesu podielu nemanželských detí. Najvyššiu váhu tak majú v súčasnosti deti narodené nevydatým ženám v stredne vel'kých mestách (20-50 tis. obyvatel'mi).

Vysvetlenie priestorových rozdielov a vzorcov častejšieho výskytu rodenia detí mimo manželstvo sa môže opierat' o kombináciu normatívnych vzorcov (najmä väčšej či menšej spoločenskej tolerancie a tým možnosti realizácie reprodukcie mimo manželský zväzok), štrukturálnych charakteristík miestnej populácie a pravdepodobne aj niektorých socioekonomických a kultúrnych aspektov daného geografického priestoru. Zaujímavostou je, že rovnako ako v susednej Českej republike (napr. Šalamounová - Šamanová 2005; Zeman 2007) aj na Slovensku môžeme identifikovat' predovšetkým prihraničný priestor $\mathrm{s}$ vyšším podielom detí rodiacich sa nevydatým ženám. Ide pritom o oblasti vyznačujúce sa aj d’alšími negatívnymi demografickými javmi, ako je napríklad vyššia rozvodovost', úmrtnost', rozvodovost'. Vyznačujú sa tiež nepriaznivou hospodárskou situáciou, ked' najmä pás juhoslovenských okresov viacerí autori (Gajdoš - Pašiak 1995; Korec 2005; Halás 2008; Halás Hurbánek 2008) označujú ako marginalizovanú periférnu oblast' so značnými a dlhodobo pretrvávajúcimi hospodárskymi problémami (vysoká a dlhodobá nezamestnanost', podpriemerné platové ohodnotenie, nízky prílev zahraničného kapitálu, nevhodná štruktúra pracovnej sily a pod.). Okrem toho z pohl'adu populačných štruktúr (Bleha a kol. 2014) sú to oblasti vyznačujúce sa výrazne vyšším podielom rómskeho obyvatel'stva (a tiež osôb mad'arskej národnosti), osôb s nízkym vzdelaním, nižšou váhou veriacich, častejším príklonom ku živote v kohabitáciách. V porovnaní s tým sú okresy severného Slovenska $\mathrm{s}$ menej častým príklonom k rodeniu detí mimo manželstva priestory s dominanciou osôb slovenskej národnosti, nadpriemerným zastúpením veriacich (najmä rímskokatolíkov), lepším vzdelanostným profilom, ako aj nižšou rozvodovost'ou a menej častým rozšírení kohabitácií. Rovnako z ekonomického hl'adiska ide o hospodársky prít’ažlivejšie a rozvinutejšie regióny.

Doterajšie získané výsledky sa opierali o agregované údaje. Dostupnost' individuálnych anonymizovaných údajov žien spolu s možnost'ou jednoznačnej 
identifikácie legitimity pôrodu umožnili aplikáciu mikroprístupu. Prostredníctvom neho sa budeme snažit' odpovedat' na otázky spojené s vybranými charakteristikami žien a úrovňou šancí stat' sa matkou diet'at'a mimo manželský zväzok. Výhodou je možnost' kontroly ostatných premenných, čo makroprístup neumožňuje a niektoré takto získané výsledky môžu byt' preto podmienené vzájomne korelujúcimi štrukturálnymi odlišnost’ami. Ked’že existujú v podstate dve základné situácie - narodenie diet'at'a v manželstve a mimo manželstvo, ako vhodným analytickým nástrojom sa ponúka binomická logistická regresia. Jej výsledky pre začiatok transformačného obdobia prvej polovice 90 . rokov a posledne známe roky prezentuje tabul'ka č. 1 .

Ako je možné na prvý pohl'ad vidiet', regresný model potvrdil v prvom i druhom sledovanom období vplyv veku ženy na šance porodit' diet'a mimo manželstvo. Vo veku do 30 rokov pritom došlo k zvýrazneniu týchto šancí, kým naopak v druhej polovici reprodukčného obdobia môžeme identifikovat' opačný trend. Súvisí to s presunom celkovej plodnosti a najmä manželskej plodnosti do vyššieho veku. Je zrejmé, že najmä v najmladšom veku je šanca na rodičovstvo mimo manželský zväzok výrazne vyššia. Napríklad v rokoch 2017 - 2019 to bolo 1,8-krát viac ako vo veku 40 a viac rokov. Model tiež potvrdil najnižšie šance nevydatých žien stat' sa matkou vo veku 25-34 rokov, teda vo veku celkovo najvyššej plodnosti, kým na začiatku 90. rokov to bolo vo veku 20-29 rokov. Rovnako je zrejmé, že aj vo veku 40 a viac rokov sú potom šance na nemanželskú plodnost' vyššie ako v hlavných reprodukčných vekoch. Z uvedených zistení tak môžeme konštatovat', že vek ženy predstavuje dôležitý faktor pre nemanželskú plodnost'. Platí, že na oboch koncoch spektra reprodukčného veku je šanca na nemanželské diet’a väčšia, pričom v poslednom období sa to týka najmä veku do 20 resp. 25 rokov (tabul'ka č. 1).

Z hl'adiska poradia narodeného diet’at'a sa potvrdilo, že najnižšie šance byt' matkou nemanželského diet'at'a majú ženy na Slovensku v prípade druhých detí a naopak najvyššie pri prvých pôrodoch. V čase pritom sa zdá, že tieto zostávajú viac menej podobné (tabul'ka č. 1).

Rovnako mikroprístup potvrdil vel'ký vplyv nízkeho vzdelania a pretrvávajúcu existenciu negatívneho vzdelanostného gradientu. Predovšetkým najmenej vzdelané ženy majú dlhodobo výrazne vyššie šance stat' sa matkou mimo manželský zväzok v porovnaní $\mathrm{s}$ vysokoškoláčkami. Vzhladom na určitý rast mimomanželskej plodnosti aj v skupine najvzdelanejších žien sa však táto disproporcia zmiernila. Na druhej strane však u stredoškolsky vzdelaných žien identifikujeme opačný jav, a teda nárast šancí stat' sa matkou nemanželského diet’at’a v porovnaní s vysokoškoláčkami (tabul'ka č. 1). 
Tabul'ka č. 1: Adjustované šance, že sa žene na Slovensku narodí diet'a mimo manželský zväzok podl'a jej vybraných sociálno-demografických charakteristík, obdobie rokov 1992 - 1994 a 2017 - 2019

\begin{tabular}{|c|c|c|c|c|c|c|}
\hline \multirow{2}{*}{ Vysvetl’ujúca premenná } & \multicolumn{3}{|c|}{ Obdobie rokov $1992-1994$} & \multicolumn{3}{|c|}{ Obdobie rokov $2017-2019$} \\
\hline & B & Sig. & $\operatorname{Exp}(B)$ & B & Sig. & $\operatorname{Exp}(B)$ \\
\hline \multicolumn{7}{|l|}{ Vek matky } \\
\hline$-19(1)$ &, 018 & ,809 & 1,018 &, 601 &, 000 & 1,824 \\
\hline $20-24(2)$ &,- 797 &, 000 &, 451 &, 123 &, 000 & 1,131 \\
\hline $25-29(3)$ &,- 730 &, 000 & ,482 &,- 398 &, 000 & ,672 \\
\hline $30-34(4)$ &,- 374 &, 000 & 688 &,- 441 &, 000 & ,643 \\
\hline $35-39(5)$ &,- 102 & ,019 & ,903 &,- 199 &, 000 & ,819 \\
\hline $40+(6)$ & ref. & ref. & ref. & ref. & ref. & ref. \\
\hline \multicolumn{7}{|l|}{ Poradie pôrodu } \\
\hline Prvý pôrod (1) & 1,146 & 0,000 & 3,146 & 1,138 & 0,000 & 3,120 \\
\hline Druhý pôrod (2) & 0,379 & 0,000 & 0,896 & 0,197 & 0,000 & 0,851 \\
\hline Tretí a d’alší pôrod (3) & ref. & ref. & ref. & ref. & ref. & ref. \\
\hline \multicolumn{7}{|l|}{ Vzdelanie matky } \\
\hline Základné a bez vzdelania (1) & 3,017 & 0,000 & 20,423 & 2,447 & 0,000 & 11,553 \\
\hline Stredoškolské bez maturity (2) & 1,080 & 0,000 & 2,943 & 1,707 & 0,000 & 5,512 \\
\hline Stredoškolské s maturitou (3) & 0,375 & 0,000 & 1,454 & 0,932 & 0,000 & 2,539 \\
\hline Vysokoškolské (4) & ref. & ref. & ref. & ref. & ref. & ref. \\
\hline \multicolumn{7}{|l|}{ Národnost' matky } \\
\hline Slovenská (1) &,- 023 & 0,000 & ,977 & 0,687 & 0,000 & 1,988 \\
\hline Mad’arská (2) &,- 058 & 0,000 & ,943 & 0,686 & 0,000 & 1,986 \\
\hline Rómska (3) &, 861 & 0,000 & 2,366 & 1,056 & 0,000 & 2,876 \\
\hline Iná (4) & ref. & ref. & ref. & ref. & ref. & ref. \\
\hline \multicolumn{7}{|l|}{ Kraj bydliska matky } \\
\hline Bratislavský (1) &, 117 & ,000 & 1,124 &, 156 &, 000 & 1,169 \\
\hline Trnavský (2) &,- 338 & ,000 & ,713 &, 149 &, 000 & 1,160 \\
\hline Trenčiansky (3) &,- 390 &, 000 &, 677 & ,068 &, 000 & 1,071 \\
\hline Nitriansky (4) &,- 223 &, 000 & 800 &, 235 &, 000 & 1,265 \\
\hline Žilinský (5) &,- 399 & ,000 &, 671 &,- 273 &, 000 & ,761 \\
\hline Banskobystrický (6) &, 054 & ,068 & 1,056 & ,328 &, 000 & 1,388 \\
\hline Prešovský (7) &,- 322 & ,000 &, 724 &,- 966 &, 000 & ,381 \\
\hline Košický (8) & ref. & ref. & ref. & ref. & ref. & ref. \\
\hline
\end{tabular}

Sociológia 53, 2021, ̌̌. 4 


\begin{tabular}{|c|c|c|c|c|c|c|}
\hline \multirow{2}{*}{ Vysvetl'ujúca premenná } & \multicolumn{3}{|c|}{ Obdobie rokov $1992-1994$} & \multicolumn{3}{|c|}{ Obdobie rokov 2017- 2019} \\
\hline & B & Sig. & $\operatorname{Exp}(\mathbf{B})$ & B & Sig. & $\overline{\operatorname{Exp}(B)}$ \\
\hline \multicolumn{7}{|c|}{ Miesto bydliska matky je mesto / vidiecka obec } \\
\hline Mestá (1) & ,077 & ,000 & 1,080 & $-0,412$ & 0,000 & 0,662 \\
\hline Vidiecke obce (2) & ref. & ref. & ref. & ref. & ref. & ref. \\
\hline \multicolumn{7}{|c|}{ Vel'kostná skupina obce miesta bydliska matky } \\
\hline do 1000 osôb (1) &,- 667 & 000 &, 513 &, 163 & 000 & 1,177 \\
\hline 1000 - 1999 osôb (2) &,- 591 &, 000 &, 554 & , 154 & 000 & 1,166 \\
\hline 2000 - 4999 osôb (3) &,- 587 & 000 &, 556 & ,132 & 000 & 1,141 \\
\hline 5000 - 9999 osôb (4) &,- 478 &, 000 & ,620 &, 111 & 000 & 1,117 \\
\hline 10000 - 19999 osôb (5) &,- 378 & 000 & 685 & 149 & 000 & 1,161 \\
\hline 20000 - 49999 osôb (6) &,- 264 &, 000 & ,768 &, 117 &, 000 & 1,124 \\
\hline 50000 - 99999 osôb (7) &,- 089 & 031 & ,915 & 197 & 000 & 1,218 \\
\hline 100000 a viac osôb (8) & ref. & ref. & ref. & ref. & ref. & ref. \\
\hline
\end{tabular}

Zdroj údajov: ŠÚSR; výpočty autorov

Šance žien porodit' diet'a mimo manželstvo so slovenskou a mad'arskou národnost'ou sa ukazujú byt' dlhodobo vel'mi podobné. V prípade žien hlásiacich sa $\mathrm{k}$ rómskej národnosti však na začiatku 90. rokov, ako aj v súčasnosti bolo toto riziko výrazne vyššie.

Výsledky regresného modelu tiež poukázali na vplyv miesta bydliska ženy. Vo viacerých prípadoch pritom mikroprístup potvrdil vyššie identifikované zistenia založené na agregovaných údajoch. Kým na začiatku transformačného obdobia boli šance na nemanželské diet’a vyššie v mestskom prostredí, v súčasnosti je to skôr na vidieku. Rovnako došlo aj v zmene šancí podl'a vel'kosti miesta bydliska. Najväčšie mestá, ktoré na začiatku 90. rokov mali jednoznačne najvyššie šance sú $\mathrm{v}$ súčasnosti priestorom s najnižším rizikom. Rozdiely medzi ostatnými vel'kostnými skupinami však zostávajú pomerne malé (tabul'ka č. 1). Dlhodobo najnižšie šance na narodenie diet'at'a mimo manželstva identifikujeme v Prešovskom a Žilinskom kraji. Opačná situácia je v Banskobystrickom a Nitrianskom kraji, do ktorých patria viaceré zo spomínaných okresov s najvyšším zastúpením nemanželských detí.

\section{Niektoré demografické aspekty rastu podielu nemanželských detí}

Teoretické koncepcie vysvetlujúce rast počtu a podielu detí narodených mimo manželstva sa vo všeobecnosti opierajú o normatívne a štrukturálne posuny. Tieto však vo svojej podstate predstavujú externé podmienenosti, ktoré môžu ale aj nemusia pôsobit' na zmeny interných (demografických) faktorov priamo prepojených so sledovaným fenoménom. Ako dodáva Rychtaříková (2006), súčasný rast počtu a podielu detí narodených mimo manželstva môže súvisiet' 
$\mathrm{s}$ transverzálnou diferencovanou zmenou $\mathrm{v}$ demografických trendoch a štruktúrach. Medzi ne môžeme v zmysle Rychtaříkovej (2006) a Smith a kol. (1996) zaradit' intenzitu manželskej plodnosti, plodnosti nevydatých žien a počet a vekovú štruktúru žien podl'a rodinného stavu. Zmena každého z týchto faktorov následne priamo ovplyvňuje počet a váhu narodených detí podl'a ich legitimity, pričom môžu pôsobit' súčasne, v rovnakom alebo opačnom smere a vo vzájomnej kombinácii (Rychtaříková 2006).

Za účelom identifikovania smeru a intenzity pôsobenia týchto faktorov na nárast podielu detí narodených mimo manželstva na Slovensku sme využili dekompozičnú techniku navrhnutú das Guptom (1994). Medzi rokom 1990 a 2019 došlo $\mathrm{k}$ nárastu nemanželských detí o takmer 32 p.b. z necelých $8 \%$ na $40 \%$. Z hl'adiska intenzít plodnosti je zrejmé, že v sledovanom období sa predovšetkým znížila intenzita rodenia detí vydatých žien v najmladšom veku (do 25 rokov). Súčasne došlo knezanedbatel'nému zvýšeniu plodnosti u vydatých žien vo veku 25-34 rokov (obrázok č. 2). Toto oživenie v podstate takmer vykompenzovalo spomínaný pokles v mladom veku. Preto sa dá povedat', že celková manželská plodnost' je v súčasnosti približne na rovnakej úrovni ako na začiatku 90. rokov. Na druhej strane v prípade plodnosti nevydatých žien môžeme vidiet', že medzi sledovanými rokmi došlo na Slovensku k jednoznačnému nárastu intenzity rodenia nemanželských detí. Tento jav sa pritom týkal všetkých vekových skupín. Najväčšiu dynamiku však zaznamenávame vo veku celkovo najvyššej plodnosti (25-29 rokov).

Obrázok č. 2: Čisté miery plodnosti vydatých a nevydatých žien na Slovensku v rokoch 1990 a 2019

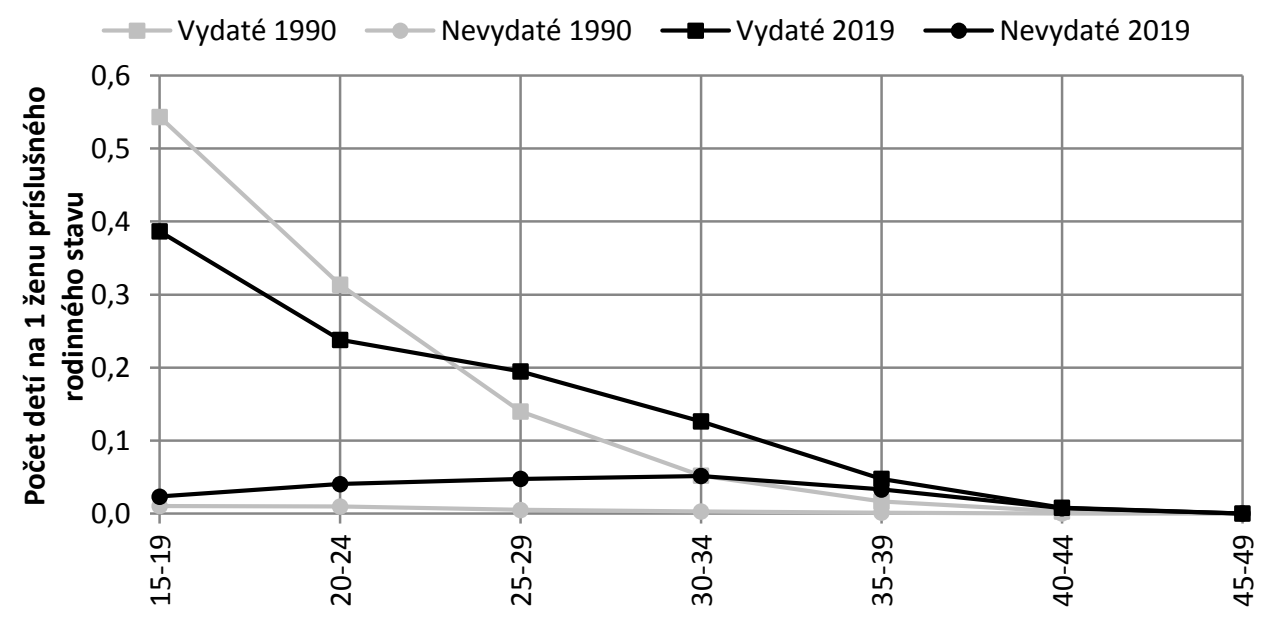

Zdroj údajov: ŠÚSR; výpočty autorov

Sociológia 53, 2021, č. 4 
Významné zmeny, ktorými prešlo rodinné správanie a najmä intenzita, časovanie sobášnosti slobodných $\mathrm{v}$ kombinácii s čoraz častejšou preferenciou alternatívnych párových zväzkov, či samotným odmietaním manželstva vyústili do dramatickej premeny štruktúry žien podl’a rodinného stavu v reprodukčnom období. Vo všetkých vekových skupinách a jednoznačne najviac vo vekoch vyznačujúcich sa najvyššou plodnost'ou došlo $\mathrm{k}$ vel'mi výraznému poklesu podielu vydatých žien (obrázok č. 3).

Rovnako dôležitou premenou prešla aj samotná veková štruktúra žien $\mathrm{v}$ reprodukčnom období (obrázok č. 4). Sme svedkami pomerne výrazného poklesu počtu žien najmä $\mathrm{v}$ jeho prvej polovici, ktoré je z hl'adiska reprodukcie rozhodujúcim. Na druhej strane nárast počtu žien vo veku 35-39 rokov a najmä 40 a viac rokov nemôže vzhl'adom na úroveň plodnosti kompenzovat' identifikované štrukturálne straty v mladších vekových skupinách.

\section{Obrázok č. 3: Zastúpenie vydatých žien na Slovensku v reprodukčnom veku v rokoch 1990 a 2019}

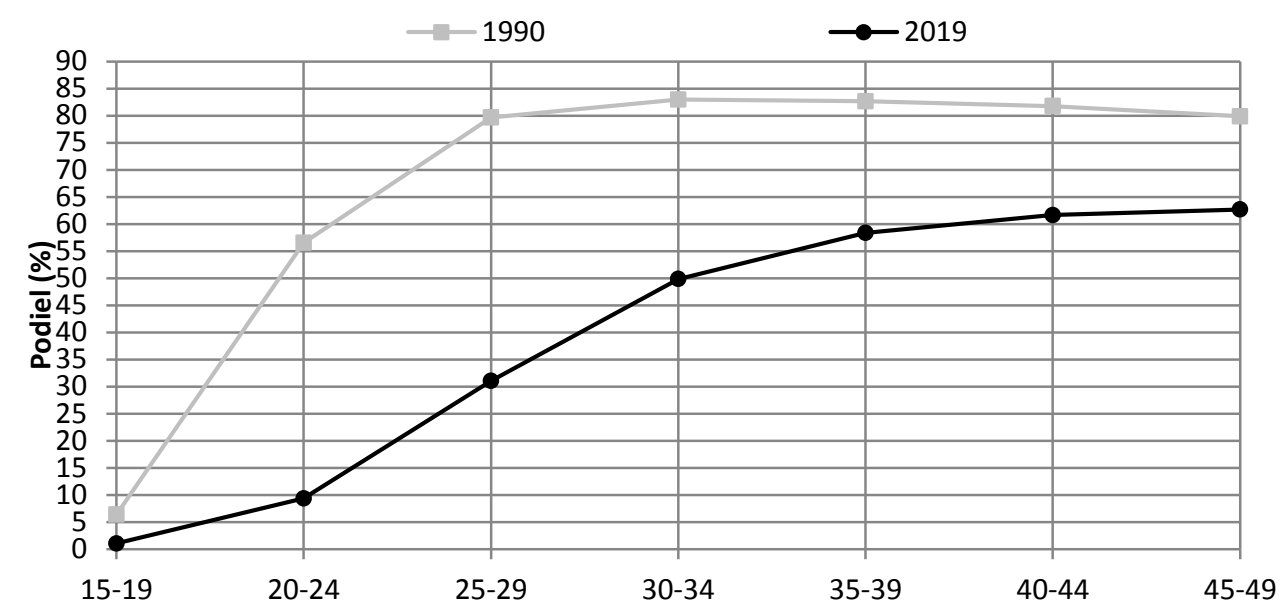

Zdroj údajov: ŠÚSR; výpočty autorov

Výsledky aplikovanej dekompozície ukazujú, že nie všetky vnútorné demografické faktory prispievali $\mathrm{k}$ identifikovanému nárastu podielu detí narodených mimo manželstvo. Ako je zrejmé z tabul'ky č. 2, v smere zvyšovania podielu nemanželských detí na Slovensku pôsobil najmä faktor zmeny štruktúry žien podla rodinného stavu (nárast o viac ako 28 p.b.). Aj ked' sa na prvý pohl'ad uvol'nil pomerne úzky vzt'ah medzi sobášnost'ou a plodnost'ou, proces odkladania vstupu do manželstva, ako aj programové odmietanie 
manželských zväzkov u určitej skupiny žien a ich nahradenie rôznymi formami párových súžití, tvoria podl’a našich zistení dominantný faktor legitimity narodených detí. Na jednej strane je to dôsledok častejšej vol'by skorého (a pravdepodobne aj osamelého) materstva mimo manželstvo u špecifickej skupiny mladých žien (napr. s nižším vzdelaním, rómskej národnosti, z juhu stredného Slovenska a pod.) a na druhej môže íst' o dôsledok existencie funkčných kohabitácií, či repetitívneho odkladania rodičovských a manželských prechodov v životných dráhach do vyššieho veku ústiacej do vol'by nemanželského materstva ako (poslednej) možnosti pre naplnenie reprodukčné zámery.

Obrázok č. 4: Zmeny vo vývoji počtu žien na Slovensku v reprodukčnom veku v rokoch 1990 a 2019

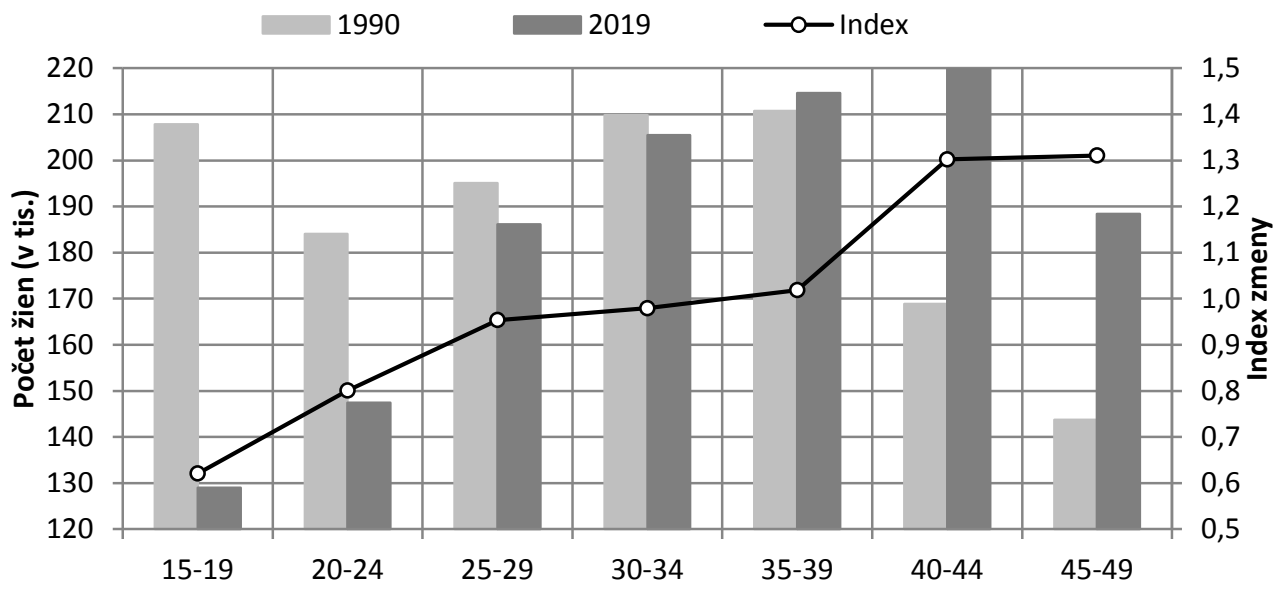

Zdroj údajov: ŠÚSR; výpočty autorov

Vd'aka zmenám v sobášnom správaní a čiastočne aj v dôsledku zvýšenia rizika rozvodu manželských zväzkov pri súčasnom poklese šancí na opakovaný vydaj (Šprocha - Tišliar 2019) sa na Slovensku celkovo výrazne početne zväčšil kontingent žien vystavených riziku narodenia nemanželského diet’ata. Súčasne s tým, ale došlo aj k d’alšiemu dôležitému javu, ktorý môžeme identifikovat' ako druhý najdôležitejší vnútorný faktor celkového nárastu podielu detí narodených mimo manželstva. Konkrétne ide o nárast intenzity rodenia detí nevydatými ženami (nárast o 12 p.b.) poukazujúci na širšiu akceptáciu tohto fenoménu. Znamená to, že v slovenskej spoločnosti došlo aj k normatívnym posunom vo vzt'ahu $\mathrm{k}$ nemanželskej plodnosti. Nárast podielu detí mimo manželstvo tak nebol len výsledkom štrukturálnych zmien.

Posuny v intenzite plodnosti vydatých žien spoločne so zmenami vekovej štruktúry žien $v$ reprodukčnom veku pôsobili proti hlavnému vývojovému 
trendu. Nárast manželskej plodnosti znižoval podiel detí narodených nevydatým ženám o takmer 7 p.b. Aj napriek výraznej premene vekovej štruktúry žien $\mathrm{v}$ reprodukčnom veku bol vplyv tohto interného demografického faktora $\mathrm{v}$ podstate zanedbatel'ný.

Tabul'ka č. 2: Absolútny a relatívny vplyv efektu vybraných faktorov na nárast podielu detí narodených mimo manželstva na Slovensku medzi rokmi 1990 a 2019

\begin{tabular}{lcc}
\hline Efekt & Absolútny vplyv & Relatívny vplyv \\
\hline zmeny vekovej štruktúry žien v reprodukčnom veku & $-1,3$ & $-4,1$ \\
zmeny štruktúry žien podl’a rodinného stavu a veku & 28,2 & 86,8 \\
zmeny intenzity plodnosti nevydatých žien & 12,4 & 38,3 \\
zmeny intenzity plodnosti vydatých žien & $-6,8$ & $-21,0$ \\
Spolu & 32,5 & 100,0 \\
\hline
\end{tabular}

Zdroj údajov: ŠÚSR; výpočty autorov

\section{Záver}

Špecifické podmienky minulého politického režimu prehĺbili v slovenskej spoločnosti inklináciu ku skorému a takmer univerzálnemu vstupu do manželstva a realizácii reprodukčných zámerov takmer výlučne v manželskom zväzku. Centrálne riadená regulácia ekonomického vývoja, populačnej a rodinnej politiky sa pretavila $\mathrm{v}$ unifikovaný demografický vývoj na makroúrovni a na štandardizované a homogenizované životné dráhy na mikroúrovni (Džamabzovič - Šprocha 2017). Prispela tiež k vzniku celého komplexu priamych i nepriamych opatrení preferujúcich manželské zväzky, a naopak znevýhodňujúcich mladé slobodné osoby s prevládajúcimi negatívnymi pohl’admi na nemanželské párové spolužitia a realizáciu reprodukčných plánov v nich alebo v podobe osamelého materstva (Džamabzovič - Šprocha 2017). $\mathrm{Na}$ nepriaznivo nastavenú populačnú klímu prevládajúcu v slovenskej spoločnosti smerom k nemanželským pôrodom poukazuje aj zvyšujúce sa zastúpenie predmanželských koncepcií.

Obdobie posledných troch desatročí prinieslo bezprecedentný nárast počtu a podielu detí narodených mimo manželstva. Diskontinuita vonkajších podmienok v úzkom prepojení s normatívnymi posunmi a transformáciou nástrojov sociálnej a rodinnej politiky prispeli $\mathrm{k}$ rozpojeniu historicky platného previazania života v manželskom zväzku s realizáciou reprodukčných zámerov. Táto skutočnost' má viaceré sociálne, psychologické, demografické i ekonomické konzekvencie a je dôležité ich zohl'adňovat' pri nastavení rodinných a sociálnych politík. 
Výsledky našich analýz však poukázali na niektoré dôležité rozdiely spojené s podielom nemanželských detí a šancou stat' sa matkou mimo manželský zväzok. Vo všeobecnosti dlhodobo platí, že najvyššie šance a najvyšší podiel nemanželských detí je spájaný s mladým a vel’mi mladým vekom. Vo veku najvyššej reprodukcie sa tieto šance výrazne znižujú, aby opätovne vzrástli s koncom reprodukčného obdobia. Môžeme tak predpokladat', že dochádza $\mathrm{k}$ určitej selekcii skupín žien. V mladom a vel'mi mladom veku ide najmä o osoby s nízkym vzdelaním, zo znevýhodneného prostredia, rómskou národnost'ou, ktoré programovo volia materstvo bez manžela v dôsledku snáh o redukciu životného rizika, ked’že na oficiálnom trhu práce sú ich šance nízke. Súčasne tieto ženy nemajú ani priaznivé vyhliadky na sobášnom trhu, a preto programovo radšej volia narodenie diet’at'a bez toho, aby so stálym partnerom (ak nejakého majú) vôbec vstúpili do manželstva. Na druhej strane vo vyššom veku môže íst' o skupinu vzdelanejších žien, ktoré odkladali materstvo, nedokázali si nájst' vhodného partnera pre založenie rodiny a slobodné materstvo je pre nich (poslednou) možnost'ou ako realizovat' svoju reprodukciu. Okrem toho môže íst' aj o koncepciu niektorých rozvedených žien, ktoré si našli d’alšieho partnera.

Značný vplyv na legitimitu narodeného diet'at'a má tiež jeho biologické poradie. Ukazuje sa, že dlhodobo najvyššie riziko stat' sa nevydatou matkou sa spája s prvým diet'at'om. Druhé a tretie deti sa naopak častejšie rodia v manželstve, aby s každým d’alším sa šance na nemanželské diet'a výrazne zvyšovali. Prvé deti mimo manželstva sú opätovne často výsledkom koncepcií v mladom veku, prípadne sú dôsledkom existencie funkčných kohabitácií, ktoré sa vzhl'adom na meniace normatívne postoje v slovenskej spoločnosti netransformujú v manželský zväzok ešte pred pôrodom. Zníženie sociálneho tlaku na prípadný sobáš tehotnej ženy pritom nepriamo poukazuje aj pokles predmanželských koncepcií.

Z hl'adiska dosiahnutého vzdelania sme potvrdili existenciu negatívneho vzdelanostného gradientu. Súčasne došlo ku značnej vzdelanostnej diferenciácii, ked’že pomerne výrazne rástlo zastúpenie nemanželských detí aj u žien so stredoškolským vzdelaním. Najtradičnejšie sa tak z hl'adiska legitimity narodených detí správajú ženy s vysokoškolským vzdelaním. Ich postavenie na sobášnom trhu je spomedzi všetkých vzdelanostných skupín najlepšie, rovnako sa vyznačujú vyššou intenzitou vstupov do manželstva, ako aj ich stabilitou. To všetko prispieva $\mathrm{k}$ častejšej realizácii reprodukčných zámerov $\mathrm{v}$ manželskom zväzku.

Výsledky nášho výskumu tiež potvrdili vplyv národnosti matky pri pôrode, ked' najmä v spojitosti so ženami deklarujúcimi rómsku národnost' platí vyšší podiel a šanca stat' sa matkou nemanželského diet’at’a. Rovnako boli potvrdené niektoré priestorové diferencie, ked' najmä pomerne rozsiahla oblast' juhu 
stredného Slovenska predstavuje centrum s častejším výskytom nemanželskej plodnosti. Opačná situácia je najmä na severe stredného a východného Slovenska. Menej dynamický rast podielu a šancí na nemanželské diet’a v najväčších mestách znamená, že tieto sa už dnes nevyznačujú nadpriemerným zastúpením a rizikom narodenia dietaata nevydatej žene. V spojitosti s predchádzajúcimi výsledkami sa tak môžeme domnievat', že dôležitú úlohu $\mathrm{v}$ tomto procese zohráva práve selekcia a koncentrácia žien $\mathrm{s}$ vyšším a najmä vysokoškolským vzdelaním, nerómskej a v prevažnej miere slovenskej národnosti, ako aj všeobecný príklon $\mathrm{k}$ rodeniu detí v neskoršom veku.

Rodenie detí mimo manželský zväzok je jedným z výsledkov celkovej pluralizácie vzorcov reprodukčného správania a prispieva tak $\mathrm{k}$ významnej heterogenizácii charakteru a štruktúr rodín a domácnosti. Zmeny pritom pozorujeme nielen $\mathrm{v}$ samotnom reprodukčnom správaní, ale aj v niektorých názoroch slovenskej verejnosti na určité oblasti rodinného, sexuálneho a reprodukčného správania prepojených s procesom rodenia nemanželských detí. Predovšetkým ide o rastúcu toleranciu k iným ako manželským formám spolužitia, ako aj k samotnému slobodnému rodičovstvu (Džambazovič Šprocha 2017). Z existencie pomerne značných rozdielov v zastúpení nemanželských detí a šanciach stat' sa nevydatou matkou môžeme jednoznačne povedat', že nárast nemanželskej plodnosti je možné na Slovensku prirovnat' k postupnej difúzii nového reprodukčného správania v spoločnosti. Potvrdilo sa, že v podstate až do konca minulého politického režimu bolo rodenie detí mimo manželský zväzok marginálnou životnou stratégiou. Akceptovala ho len určitá minoritná čast' populácie (napr. ženy s nízkym vzdelaním, rómskej národnosti a pod.). Spočiatku tak išlo o selektívny jav týkajúci sa vybraných sociálnych skupín. Rovnako aj vývoj v transformačnom období potvrdil, že aj ked' dochádzalo k širšej akceptácii nemanželských detí v slovenskej spoločnosti, dynamikou šírenia a rozsahom samotnej akceptácie sa jednotlivé skupiny stále od seba odlišujú. Na druhej strane sa dá povedat', že s prenikaním tohto fenoménu do čoraz vä̌̌šej časti sociálnych skupín v populácii Slovenska prestávajú prvotné faktory selektivity zohrávat' svoju determinujúcu úlohu. Významné premeny $\mathrm{v}$ životných dráhach mladých l'udí prinášajú ich deštandarizáciu a nárast heterogenity, čím sa vytvára stále väčší priestor na rôzne vol'by a nastavenie prechodov $\mathrm{k}$ materstvu a rodičovstvu. Sme svedkami pluralizácie ciest k napíñaniu reprodukčných zámerov, ako aj samotných dráh smerujúcich $\mathrm{k}$ vol'be materstva mimo manželský zväzok.

Zo získaných výsledkov nie je možné jednoznačne odpovedat' na otázku, ktorý $\mathrm{z}$ teoretických rámcov najlepšie vystihuje proces šírenia fenoménu nemanželskej plodnosti na Slovensku. Domnievame sa, že takáto identifikácia ani nie je možné, pretože $\mathrm{v}$ rôznych skupinách môžu uvedené faktory pôsobit' v rôznej intenzite. Navyše sa dá očakávat', že s postupným priebehom 
transformačného obdobia dochádzalo aj k určitej premene ich vplyvu. Preto len priamočiare vysvetl'ovanie skrz prizmu posunov v hodnotách a normách, ktoré sú klúčcovým bodom druhej demografickej revolúcie, nie je zdá sa úplne postačujúce, ked’že zmeny v nemanželskej plodnosti sa dotýkajú predovšetkým žien s nízkym vzdelaním, zo znevýhodneného prostredia, z priestorov vyznačujúcich sa dlhodobo ekonomickými problémami. Naopak vo vel'kých mestách, u žien s vysokoškolským vzdelaním tieto zmeny neprebiehajú ani zd’aleka tak dynamicky. Preto sa domnievame, že štrukturálne faktory a teória redukcie neistoty by aj v prípade Slovenska mohla zohrávat' dôležitú úlohu pri vysvetl'ovaní predmetného fenoménu. Súčasne je však tiež jasné, že uvedené posuny sú tiež súčast'ou biografie žien stojacich na vyššom spoločenskom rebričcku, s lepším vzdelaním, ekonomickým zabezpečením a pod. Preto môžeme predpokladat' vhodnú kombináciu štrukturálnych a normatívnych faktorov cielene pôsobiacich $\mathrm{v}$ jednotlivých sociálnych skupinách a formujúcich rozhodovacie procesy na ceste $\mathrm{k}$ vol'be $\mathrm{k}$ materstvu mimo manželský zväzok.

Z hladiska vnútorných demografických faktorov však naše zistenia celkom jednoznačne určili, že dominantným procesom spojeným s historicky nebývalým nárastom podielu detí narodených mimo manželstvo na Slovensku predstavuje zväčšenie kontingentu nevydatých a najmä slobodných žien v reprodukčnom veku podporený navyše aj zvýšením samotnej intenzity rodenia nemanželských detí. Svedčí to nielen o štrukturálnych posunoch, ale nepriamo aj o spomínanej akceptácii nemanželskej plodnosti ako takej.

Branislav Šprocha absolvoval magisterské a doktorandské štúdium (2011) na Př́rodovědecké fakultě Univerzity Karlovy v Prahe v odbore demografia. V roku 2021 sa habilitoval v programe humánna geografia. Od roku 2007 je vedecko-výskumným pracovníkom Inštitútu informatiky a štatistiky vo Výskumnom demografickom centre $v$ Bratislave a od roku 2009 vedeckým pracovníkom Centra spoločenských a psychologických vied SAV. V oblasti demografie sa špecializuje na problematiku sobášnosti, rozvodovosti, populačného vývoja, transformácie reprodukčného správania po roku 1989 a jeho dopadov na spoločnost'. Okrem toho sa venuje tiež analýze vybraných populačných štruktúr, reprodukčného správania rómskeho obyvatel'stva na Slovensku a problematike populačného prognózovania.

Pavol Tišliar absolvoval štúdium archívnictva, pomocných vied historických a histórie na Univerzite Komenského v Bratislave. Je profesorom slovenských dejin (2015) so zameraním najmä na oblast' historickej demografie Slovenska. Pôsobí na Ústave archeologie a muzeologie na Filozofickej fakulte Masarykovej univerzite v Brne. Voblasti demografie sa venuje populačnému vývoju Slovenska $v$ historickom diskurze 19. a 20. storočia. 


\section{LITERATÚRA}

ARNETT, J., 2004: Emerging Adulthood. The Winding Road from Late Teens through the Twenties. Oxford: Oxford University Press.

BARTOŇOVÁ, D., 2001: Demografické chování populace České republiky v regionálním a evropském kontextu. In: M. Hampl a kol.: Regionální vývoj: specifika české transformace, evropská integrace a obecná teorie. Praha: Univerzita Karlova v Praze, Př́rodovědecká fakulta, Katedra sociální geografie a regionálního rozvoje, S. 45-74.

BLEHA, B. - VAŇO, B. - BAČÍK, V. (eds.), 2014: Demografický atlas Slovenskej republiky. Bratislava: Geografika.

BLEHA, B. a kol., 2020: Analýza demografického vývoja oblastí a obcí podl'a štatútu a vel'kosti v Slovenskej republike. Bratislava: INFOSTAT.

BUDILOVÁ, L. - JAKOUBEK, M., 2004: Příbuzenství v romské osadě. In: M. Jakoubek, T. Hirt eds. Romové: Kulturologické etudy. Plzeň: Vydavatelství a nakladatelství Aleš Čeněk, s.r.o., s. 9-64.

DAS GUPTA, P., 1994. Standardization and Decomposition of Rates: A User's Manual. Bureau of The Census, Current Population Reports, Special Studies P23186.

DŽAMABZOVIČ, R., 2012: Rodinné správanie v demografických dátach. Bratislava: STIMUL.

DŽAMBAZOVIČ, R., 2015: Reprodukčné a rodinné správanie na Slovensku (sociologická interpretácia trendov). In: I. Chovát, R. Džambazovič (eds.) Rodina na Slovensku v teórii a vo výskume. Bratislava: STIMUL, s. 11-51.

DŽAMBAZOVIČ, R. - ŠPROCHA, B., 2017: Kto žije v kohabitáciách na Slovensku? Intenzita vytvárania a charakteristiky kohabitujúcich osôb podl'a výsledkov sčítania obyvatel'ov, domov a bytov 2011. Sociológia 49(4): 369-404.

EDIN, K., 2000: What Do Low-Income Single Mothers Say about Marriage? Social Problems, 47(1): 112-133. https://doi.org/10.1525/sp.2000.47.1.03x0282v

ESTEVE, A. - LESTHAEGHE, R. - LOPEY-GAY, A., 2012: The Latina American Cohabitation Boom, 1970 - 2007. Population and Development Review 38(1): 5881. https://doi.org/10.1111/j.1728-4457.2012.00472.x

FILADELFIOVÁ, J. - CUPEROVÁ, K., 2000: Rôznorodost' demografického vývoja v Európe. Bratislava: MS ŠR.

FRIEDMAN, D. - HECHTER, M. - KANAZAWA, S., 1994: A Theory of the Value of Children. Demography 31(3): 375-401. https://doi.org/10.2307/2061749

GAJDOŠ, P. - PAŠIAK, J., 1995: Vývoj sociálno-ekologickej situácie slovenskej spoločnosti. Bratislava: VEDA.

HALÁS, M., 2008: Priestorová polarizácia spoločnosti s detailným pohl'adom na periférne regióny Slovenska. Sociologický časopis 44(2): 349-369. https://doi.org/10.13060/00380288.2008.44.2.06

HALÁS, M. - HURBÁNEK, P., 2008: Identifikácia a klasifikácia periférnych regiónov (pokus o syntézu). In: Periférnost' a priestorová polarizácia na území Slovenska. Bratislava: Geografika, s. 109-136.

HAMPLOVÁ, D., 2007: Děti bez manželství nebo bez otců. Data a výzkum - SDA Info $(1,2)$ : 141-154. 
HAMPLOVÁ, D. - ŘEHÁKOVÁ, B., 2006: Mimomanželská plodnost: individuální charakteristiky žen a vliv regionu. In: D. Hamplová (ed.) Mimomanželská plodnost v České republice po roce 1989: sociální a ekonomické souvislosti. Sociologické studie 06/05. Praha: Sociologický ústav AV ČR, s. 26-39.

CHALOUPKOVÁ, J., 2007: Diferenciace motivů svobodného mateřství: proč neprovdané matke nevstoupily před narozením svého přvního dítěte do manželství? Data a výzkum - SDA Info $(1,2): 127-140$.

JURČOVÁ, D. a kol., 2010: Populačný vývoj v okresoch Slovenskej republiky 2009. Bratislava: INFOSTAT.

KATRŇÁK, T., 2006: Kdo jsou svobodné matky v české společnosti? In: J. Kocourková, L. Rabušic (eds.): Sňatek a rodina: zájem soukromý nebo veřejný? Praha: Univerzita Karlova v Praze, Př́rodovědecká fakulta, s. 45-55.

KOREC, P., 2005: Regionálny rozvoj Slovenska v rokoch 1989 - 2004. Bratislava: Geografika.

KUIJSTEN, A., 1995: Recent Trends in Households Structures. In: E. Van Imhoff, A. Kuijsten, P. Hooimeijer, L. Van Wissen (eds.): Household Demography and Household Modeling. New York: Plenum Press., s. 53-84. https://doi.org/10.1007/978-1-4757-5424-7_3

KVAPILOVÁ, E., 2000: Rôznorodost' rodinných foriem - výzva pre sociálnu politiku. Sociológia 32(5): 435-448.

LESTHAEGHE, R., 1995: The Second Demographic Transition in Western Countries: An Interpretation. In: K. O. Mason, A. M. Jenses (eds.): Gender and Family Change in Industrialized Countries. Oxford: Claredon Press, s. 17-62

LESTHAEGHE, R., 2010: The Unfolding Story of the Second Demographic Transition. Population and Development Review 36(2): 211-251. https://doi.org/10.1111/j.1728-4457.2010.00328.x

LESTHAEGHE, R. - MOORS, G., 2000: Recent Trends in Fertility and Household Formation in the Industrialized World. Review of Population and Social Policy (9): 121-170.

LESTHAEGHE, R. - SURKYN, J., 2002: New Forms of Household Formation in Central and Eastern Europe: Are they Related to Newly Emerging Value Orientations? Economic Survey of Europe 2002/1. Economic Comission for Europe, United Nations, New York and Geneva, s. 197-216.

MLÁDEK, J. - ŠIROČKOVÁ, J., 2004: Kohabitácie ako jedna z foriem partnerského spolužitia obyvatel'stva Slovenska. Sociológia 36(5): 423-454.

MONNIER, A. - RYCHTAŘÍKOVÁ, J., 1992: The Division of Europe into East and West. Population: An English Selection (4): 129-160.

MOŽNÝ, I., 1987: K některým novým jevům v kulturně legitimních vzorcích rodinných startů. Demografie 29(1): 114-123.

MOŽNÝ, I. - RABUŠIC, L., 1992: Unmarried Cohabitation in Czechoslovakia. Czechoslovak Sociological Review 28(Special Issue): 107-117.

NÍ BHROLCHÁIN, M., 1993: East-West Marriage Contrast, Olds and New. In: A. Blum, J.-L. Rallu (eds.): European Population II. Demographic Dynamics. Paris: John Libey, INED, s. 461-479. 
NÝVLT, O. - ŠALAMOUNOVÁ, P., 2004: Mimomanželská plodnost v České republice. SDA Info VII(1): 1-5.

POTANČOKOVÁ, M., 2009: Reproductive Carrers of Women in Slovakia during the State Socialist Era of the 1970s and in Transforming Society. Dizertačná práca. Praha: Katedra demografie a geodemografie, Př́rodovědecká fakulta Univerzity Karlovy.

POTANČOKOVÁ ,M., 2012: Plodnost'. In: B. Vaňo (ed.): Populačný vývoj v Slovenskej republike 2011. Bratislava: INFOSTAT, s. 29-42.

POTANČOKOVÁ, M., 2013: Rodina a životné dráhy mladých dospelých. In: V. Krivý (ed.): Ako sa mení slovenská spoločnost'. Bratislava: IRIS, s. 89-127.

POTANČOKOVÁ, M. - VAŇO, B. - PILINSKÁ, V. - JURČOVÁ, D., 2008: Slovakia: Fertility between Tradition and Modernity. Demographic research 19(7): 9731018. https://doi.org/10.4054/DemRes.2008.19.25

RYCHTAŘÍKOVÁ, J., 2006: Být svobodnou matkou v České republice. In: J. Kocourková, L. Rabušic (eds): Sňatek a rodina: zájem soukromý nebo veřejný? Praha: Univerzita Karlova v Praze, s. 20-44.

SALNER, P., 1984: Postavenie slobodnej matky $\mathrm{v}$ dedinskom spoločenstve $\mathrm{v}$ prvej polovici 20. storočia. Národopisné informácie (3): 82-86.

SMITH, H. L. - MORGAN, P. - KOROPECKYJ-COX, T., 1996: A Decomposition of Trends in the Nonmarital Fertility Ratios of Black and Whites in the United States, 1960 - 1992. Demography 33(2): 141-151. https://doi.org/10.2307/2061868

SOBOTKA, T., 2002: Ten Years of Rapid Fertility Changes in the European PostCommunist Countries. Evidence and interpretation. Population Research Centre, University of Groningen, Working Paper Series 02-1, july 2002.

SOBOTKA, T., 2004: Postponement of Childbearing and Low Fertility in Europe. Groningen: Rijksuniversiteit Groningen.

SOBOTKA, T., 2011: Fertility in Central and Eastern Europe after 1989: Collapse and Gradual Recovery. Historical Social Research 36(2): 246-298.

SOBOTKA, T. - ZEMAN, K. - KANTROOVÁ, V., 2003: Demographic Shift in the Czech Republic after 1989: A Second Demographic Transition View. European Journal of Population 19(3): 249-277. https://doi.org/10.1023/A:1024913321935

SOBOTKA, T. - TOULEMON, L., 2008: Changing Family and Partnership Behaviour: Common Trends and Persistent Diversity across Europe. Demographic Research 7(4): 85-138. https://doi.org/10.4054/DemRes.2008.19.6

SULLEROTOVÁ, E., 1998: Krize rodiny. Praha: Karolinum.

SURKYN, J. - LESTHAEGHE, R., 2004: Values Orientation and the Second Demographic Transition (SDT) in Northern, Western and Southern Europe: An Update. Demographic Research (S3): 45-86. https://doi.org/10.4054/DemRes.2004.S3.3

ŠALAMOUNOVÁ, P. - NÝVLT, O., 2006: Mimomanželská plodnost - současné trendy v Evropě a v České republice. In: D. Hamplová, P. Šalamounová, G. Šamanová: Životní cyklus. Sociologické a demografické perspektivy. Praha: Sociologický ústav AV ČR, s. 118-140.

ŠALAMOUNOVÁ, P. - ŠAMANOVÁ, G., 2005: Plodnost z hlediska legitimity v regionálním pohledu. SDA Info VII(2): 6-9. 
ŠPROCHA, B., 2014: Reprodukcia rómskeho obyvatel'stva na Slovensku a prognóza jeho populačného vývoja. Bratislava: PÚ SAV.

ŠPROCHA, B. - DŽAMBAZOVIČ, R., 2020: Kto s kým vstupuje do manželstva na Slovensku? K niektorým aspektom výberu manželského partnera v rokoch 1992 2018. Sociológia52(4): 374-402. https://doi.org/10.31577/sociologia.2020.52.4.16

ŠPROCHA, B. - ĎURČEK, P., 2017: Rómovia na Slovensku v sčítaniach obyvatel'ov 1980 - 2011. Bratislava: INFOSTAT.

ŠPROCHA, B. - TIŠLIAR, P., 2008: Plodnost' a celková reprodukcia obyvatel'stva Slovenska v rokoch 1919 - 1937. Bratislava: STIMUL.

ŠPROCHA, B. - TIŠLIAR, P., 2016: Transformácia plodnosti žien Slovenska v 20. a na začiatku 21. storočia. Bratislava: Centrum pre historickú demografiu a populačný vývoj Slovenska FiF UK Bratislava.

ŠPROCHA, B. - TIŠLIAR, P., 2018: 100 rokov obyvatel'stva Slovenska. Od vzniku Československa po súčasnost'. Bratislava: Centrum pre historickú demografiu a populačný vývoj Slovenska FiF UK Bratislava.

ŠPROCHA, B. - TIŠLIAR, P., 2019: Najvyššie dosiahnuté vzdelanie a jeho vplyv na transformujúce sa rodinné a reprodukčné správanie žien na Slovensku. Bratislava: PÚ SAV, Centrum spoločenských a psychologických vied SAV.

ŠPROCHA, B. a kol., 2019: Populačný vývoj v krajoch a okresoch Slovenska od začiatku 21. storočia. Bratislava: INFOSTAT.

ŠVECOVÁ, A., 1997: Rodina a dedina. In: M. Botíková. K. Jakubíková, S. Švecová (eds.): Tradície slovenskej rodiny. Bratislava: VEDA, s. 50-60.

TIŠLIAR, P., 2013: Náčrt populačnej politiky na Slovensku v rokoch 1918 - 1945. In: P. Tišliar (ed.): Populačné štúdie Slovenska I. Krakov: Spolok Slovákov v Pol'sku, S. 19-90.

TYDLITÁTOVÁ, G., 2015a: Vol'ba nezosobášeného spolužitia v podmienkach sociálneho a situačného tlaku. Sociológia 47(2): 191-216.

TYDLITÁTOVÁ, G., 2015b: Nezosobášené spolužitia mladej generácie na Slovensku a ich podmieňujúce aspekty. In: I. Chovát, R. Džambazovič (eds.): Rodina na Slovensku v teórii a vo výskume. Bratislava: STIMUL, s. 133-154.

VAN DE KAA, D. J., 1987: Europe's Second Demographic Transition. Population Bulletin,42. Washington: The Population Reference Bureau.

VAN DE KAA, D. J., 1994: The Second Demographic Transition Revisited: Theories and Expectations. In: G. Beets et al.: Population and Family in the Low Countries 1993: Late Fertility and other Current Issues. Berwyn/Amsterdam: Swets and Zeitlinger, s. 81-126.

VAN DE KAA, D. J., 1997: Options and Sequences: Europe's Demographic Patterns. Journal of the Australian Population Association 14(1): 1-30. https://doi.org/10.1007/BF03029484

VASKOVICS, L., 2001: The Sociological Theory of Post-Adolescence. Review of Sociology 11(1): 5-20. https://doi.org/10.1556/RevSoc.7.2001.1.1

VAŠKOVÁ, R., 2006: Rozhodovací procesy náctiletých matek vedoucí k volbě časného rodičovství. In: D. Hamplová, P. Šalamounová, G. Šamanová (eds.): Životní cyklus: Sociologické a demografické perspektivy. Praha: Sociologický ústav AV ČR, s. 79-117. 
VONDRÁČKOVÁ, L. - CHROMKOVÁ MANEA, B. - LAKOMÝ, M., 2014: Rodičovství mimo manželství. In: P. Fučík, B. Chromková Manea (eds.): Rodičovské dráha. Dvacet let vývoje české porodnosti v sociologické perspektivě. Brno: Masarykova univerzita, s. 143-175.

WALTER, M. R., 2001: High Hopes: Unwes Parent's Expectations about Marriage. Children and Youth Services Review 23(6-7): 457-484. https://doi.org/10.1016/S0190-7409(01)00144-X

ZEMAN, K., 2007: Nemanželská plodnost demografický přehled. In: D. Hamplová (ed.): Děti na psí knížku? Mimomanželská plodnost v ČR. Praha: Sociologický ústav AV ČR, s. 17-28. 